\title{
Introduction
}

In 1845 Thomas Laycock sent a copy of his recently published paper 'On the reflex function of the brain' to William Pulteney Alison, Professor of the Practice of Physic at the University of Edinburgh. ${ }^{1}$ Ten years later, against all expectations, he became Alison's successor. Until the Universities (Scotland) Act of 1858 brought Edinburgh more into conformity with the general model of government found in British universities, the patronage of this and most other professorships was vested in the local Town Council. More often than not, the suffrages of councillors had to be won through keen and sometimes acrimonious contests between candidates. In some quarters it was believed that the Town Council's decisions were subject to a range of religious, national and political prejudices. How, then, did a provincial English physician who had received no part of his education at Edinburgh and who only had a handful of acquaintances there, come to be elected primus inter pares of the University Medical Faculty?

Precisely this question exercised Laycock's own pen for many years afterwards. The end result was the 'Account'. It is an apologia-the work of a man writing to set the record straight. He commenced it five years to the day after his campaign began. Further important additions were made in 1866 while he was recuperating from an amputation above the knee. Laycock continued to include material until 1875, the year before his death, the last identifiable and highly significant item being an obituary of his rival for the chair, John Hughes Bennett. Its drawn-out composition helps to explain why the final narrative encompassed his subsequent dispute about the teaching of clinical medicine at the Royal Infirmary (1857) and the contest for the University principalship involving Sir Alexander Grant and Sir James Young Simpson (1868).

Throughout the 'Account', Laycock's primary aim was an autobiographical vindication of his own conduct and position, while exposing what he saw as the shortcomings of others, especially some of his colleagues in the Medical Faculty. His concern with written self-justification was an obsession from a relatively early age. It frequently reveals itself in the 'Journal' which he commenced in 1833, when a student at the Medical School of London University, and continued sporadically until 1857. His Correspondence and statements is in a similar vein. As an apologia, however, the 'Account' took on a very unusual form, one quite different from the 'Journal'. It was not a diary written in the heat of the moment but a product of delayed reflection. Laycock scrupulously referred to himself in the third person throughout and made repeated reference to the letters, press cuttings, voting lists and other documents he had collected. He even went so far as to include photographs and lithographic prints of the dramatis personae in his story. It seems that the man who claimed he put forward his credentials for the professorship in the form of a case to be heard before judges in a special court, adopted precisely the same approach in the 'Account', but with one important difference. The "evidence" was presented in the

\footnotetext{
1 Thomas Laycock, 'On the reflex function of the brain', Br. for. med. Rev., 1845, 19: 298-311.
} 


\section{Michael Barfoot}

closed and very private session of a manuscript, one which he could never publish and by it stimulate that "feeling of justice in the public mind" (J, 242) he always craved but never attained. This concern to support his narrative with documentary material of various kinds has led to a complex source which I believe will be of great interest to historians, irrespective of their particular concerns and historiographic tastes.

No one can study history without confronting at least some of the historiographic problems writing it entails. The long-standing debate about the respective value of "objective" and "subjective" approaches, not to say the whole question of the rhetorical nature of historical narrative, is more poignant than ever. However, particular narratives and their sources are rarely brought into an examinable juxtaposition, yet this is always necessary to understand how history is actually made. In this instance, it is possible to examine the interrelationship between Laycock's interpretation of events and what we know of those same events from sources gathered by Laycock himself, as well as other related material. Moreover, this can be done taking into consideration what can be gleaned of his character, beliefs and his experience of the vicissitudes of nineteenth-century medical life. The personal and public circumstances under which he composed the 'Account' are also relevant. There is no doubt that subsequent events, such as his controversy about the teaching of clinical medicine and the reform of Edinburgh University in 1858, shaped his narrative in important ways. In my view, it is just as important to grasp the nature and ramifications of these complex interrelationships between text, personality and context as it is to understand the historical content of the manuscript itself. Nor in the end are these tasks separable. The editorial apparatus used for the Main Text and the manner in which the accompanying documentary material has been re-organised are discussed above. The overall purpose is to make it easier for the reader to study the sources separately as well as in conjunction with the particular uses Laycock made of them. In addition, a brief Chronology of the important events in Laycock's life and work is provided, together with a Biographical List of Significant Edinburgh Medical Men mentioned in the Main Text.

In this introductory essay, Laycock's career, character and writings, and the midnineteenth-century background to disputes between Edinburgh's University and its Town Council are all brought to bear upon the episodes he discussed in the main narrative. The purpose, however, is not to offer an "objective" historical judgement either of Laycock or the episodes he described. Rather, I hope that the orchestration of voices in this bookLaycock's, those of his supporters and detractors, and my own in the dual role as conductor of this introductory essay and transcriber of the score-will return the responsibility of making history to the reader where, in my view, it rightly belongs.

\section{"To fill the chair of Gregory and Cullen" (A, 53)}

On 13 August 1855 J. Y. Simpson, Professor of Medicine and Midwifery and the Diseases of Children at Edinburgh University, wrote to Dr Thomas Laycock at his home in Museum Street, York, with news that the resignation of William Pulteney Alison was imminent (A, 53). The Chair of the Practice of Physic, which Alison had occupied in so singular and distinguished a manner, would have to be filled before the winter session of medical classes commenced early in November. Simpson described the position as the 


\section{Introduction}

highest of its kind in Scotland and therefore, he said, in Great Britain as a whole. He added that the patronage of the chair was in the hands of Edinburgh Town Council "who always str[o]ve to put the right man in the right place"; that none of the other professors could or would interfere in any way; and finally, that he did not know in whose favour the election would terminate, or even whom the candidates were going to be. He wrote: "perhaps it would be a professorship for which you would consider it right to come forward". If so, he urged Laycock to act immediately rather than think it over for too long. Simpson concluded by sending his regards to Miss Laycock, when the Laycocks actually had a young son. Had his colleagues in Edinburgh University's Faculty of Medicine seen this letter, they would have instantly recognised that characteristic blend of sound and mistaken assertion for which Simpson was renowned.

For many years afterwards, Laycock puzzled over why he had been encouraged to apply. Yet all but the most crass of Simpson's strategies must have presupposed that Laycock was a credible candidate, someone with an established reputation which made him worthy of the position he sought. In fact this was more apparent to members of the Town Council and the many others who became involved in his election than it is to us today. Until recently, appreciation of Laycock has been restricted to brief biographical details, ${ }^{2}$ personal reminiscences, ${ }^{3}$ and minor notes in histories of psychiatry. ${ }^{4}$ Since the 1960s, his contributions to physiological psychology and the foundations of modern neuroscientific concepts, such as the reflex function of the brain and psycho-physical parallelism, have received detailed scholarly attention, although the basis of his reputation as a medical man still remains largely undisclosed. ${ }^{5}$ How Laycock stood in the eyes of the

\footnotetext{
2 For obituaries, see Evening Courant, 22 September 1876; Edinb. med. J., 1876, 22: 476-9; Proc. R. Soc. Edinb., 1875-8, 9: 223-5; Lancet, 1876, i: 483-4; Br. med. J., 1876, ii: 448-9; Med. Tms Gaz., 1876, ii: 449-50; Proc. R. Med. Chir. Soc. Lond., 1876, 7: 193-6; Robert Thin, College portraits: being biographical sketches in the hall of the Royal College of Physicians of Edinburgh, Edinburgh, Oliver and Boyd, 1927, pp. 88-90.

${ }^{3}$ Kenneth Macleod, 'Laycock', Caled. med. J., 1907-9, 7: 332-52; Keith Norman Macdonald, 'Recollections of the medical "giants" of Edinburgh in the early fifties', ibid., 1907-9, 7: 94-102, pp. 96, 100, 102; James Crichton-Browne, Victorian jottings from an old commonplace book, London, Etchells and Macdonald, 1926, pp. 36-8, 45; Robert Saundby, 'An inaugural address on medical education, past and present', Br. med. J., 1911, ii: 1053-7, on p. 1054; Anon., 'An Anglo-Indian's recollections of the Edinburgh medical school from under the punkah at Trichinopoly', Chamb. J., 1897-8, 1: 254-6, 261-4, on p. 264; Alisma, Reminiscences of a student's life in the seventies, Edinburgh, Oliver and Boyd, 1918, pp. 92-4; Byrom Bramwell, 'The Edinburgh Medical School and its professors in my student days, 1865-69', Edinb. med. J., 1923, 30: 133-56, pp. 144-5; Rosalba Davico (ed.), The autobiography of Edward Jarvis, London, Wellcome Institute for the History of Medicine, 1992 (Med. Hist., Supplement No. 12), pp. 145-6.

${ }^{4}$ T. S. Clouston, 'Modern medico-psychology and psychiatry: the men who have made modern psychiatry', Hospital, 1894, 16: 114; George M. Robertson, 'The history of the teaching of psychiatry in Edinburgh: and Sir Alexander Morison', Edinb. med. J., 1928, i: 192-205, on pp. 199-200; Franz G. Alexander and Sheldon T. Selsnick, The history of psychiatry: an evaluation of psychiatric thought and practice from prehistoric times to the present, London, Allen and Unwin, 1967, p. 160; Richard Hunter and Ida Macalpine, Three hundred years of psychiatry 1535-1860: a history presented in selected texts, London, Oxford University Press, 1963, pp. 1079-80; Allan Beveridge, 'Thomas Clouston and the Edinburgh School of Psychiatry', in German E. Berrios and Hugh Freeman (eds), 150 years of British psychiatry, 1841-1991, London, Gaskell, 1991, pp. 359-88, on pp. 361, 371-2.

5 M. Peter Amacher, 'Thomas Laycock, I. M. Sechenov, and the reflex arc concept', Bull. Hist. Med., 1964, 38: 168-83; Roger Smith, 'Physiological psychology and the philosophy of nature in mid-nineteenth century Britain', PhD thesis, University of Cambridge, 1970, pp. 69-100, 255-63; L. S. Jacyna, 'Somatic theories of mind and the interests of medicine in Britain, 1850-1879', Med. Hist., 1982, 26: 233-58; Edwin Clarke and L. S. Jacyna, Nineteenth-century origins of neuroscientific concepts, Berkeley, University of California Press, 1987, pp. 127, 140-56; Kurt Danziger, 'Mid-nineteenth-century British psycho-physiology: a neglected chapter
} 


\section{Michael Barfoot}

patrons and his peers depended on what sort of a man he was, the depth of his medical experience of disease and its treatment, as well as his publications which were considerable. $^{6}$

\section{"My poverty and low birth are evidently the obstacles" (J, 235)}

Laycock possessed few of the material and social advantages which helped many others to compete successfully in the pell-mell of nineteenth-century medical life. ${ }^{7} \mathrm{He}$ was born on 12 August 1812 at Wetherby, one of the small settlements in the neighbourhood of York where his father had been sent as Wesleyan Methodist preacher. Of eight children, four survived and only two of those, including Laycock himself, lived beyond thirty. The family lived in modest circumstances. Laycock's mother had married beneath herself socially. What little capital they possessed was probably due to her dowry as the daughter of a landed gentleman with an estate at Sealand near Chester. The family may have lacked money but they made up for it in religion, morals, and learning. Thomas received a good grounding in classics at the Methodist Woodhouse Grove School $(\mathrm{J}, 18)$. When he was apprenticed to William and John Spence, surgeons at Bedale near Rippon, the Wesleyan Connexion once again came to the family's aid and paid his indenture fees. Laycock began his trade at the age of fifteen. For five years he laboured, first as a shop-boy compounding medicines; later he accompanied his master on visits to patients. Finally, towards the end of his term, he began to see the sick on a more independent basis, working voluntarily at the Bedale Dispensary. ${ }^{8}$

When this stage of his medical training was over, the time came for him to proceed to the Medical School of London University. His father died shortly beforehand. Separated from his mother, family, friends, and no longer a part of the narrow but secure professional circumstances he formerly occupied, the 21-year-old took solace in self-expression and began his 'Journal'. Its ostensible and rather pretentious aim was to keep a record of his thoughts and feelings so as to "judge of the progress" his mind might make "in developing its powers" $(\mathrm{J}, 1)$. What it rapidly became was an intellectual and spiritual diary, set against the backdrop of London life as it appeared to a young, inexperienced medical student living there in the early $1830 \mathrm{~s}^{9}$

in the history of psychiatry', in William R. Woodward and Mitchell G. Ash (eds), The problematic science: psychology in nineteenth-century thought, New York, Praeger, 1982, pp. 119-46; Alex Leff, 'Thomas Laycock and the cerebral reflex: a function arising from and pointing to the unity of Nature', Hist. Psychiat., 1991, 2: 385-407.

${ }^{6}$ There is no available bibliography of Laycock's writings after 1855, and estimates of the total number of his publications vary from 200 to 300 . For the most recent summary of Laycock's life and work see Joy Pitman, 'Thomas Laycock', Proc. R. Coll. Phys. Edinb., 1992, 22: 384-9.

${ }^{7}$ On the nineteenth-century British medical background, see Irvine S. Loudon, Medical care and the general practitioner, 1750-1850, Oxford University Press, 1987; Ivan Waddington, The medical profession in the Industrial Revolution, Dublin, Gill and Macmillan, 1984; M. Jeanne Peterson, The medical profession in midVictorian London, Berkeley, University of California Press, 1978; Charles Newman, The evolution of medical education in the nineteenth century, London, Oxford University Press, 1957.

${ }^{8}$ Biographical details based on information from the Wesleyan Historical Society Library; Laycock Papers, EUL MS Gen 1960; Laycock to Edwin Chadwick, 13 March [1843], Chadwick Papers, in UCL MS 1197.

${ }^{9}$ See also T. Stirling Boyd, A Journal. 1833-1857 by Thomas Laycock M.D., from the transcript of the original manuscript (beginning in 1833 when he came to London to study medicine at the University of London), Laycock Papers, EUL MS Gen 1960/1. This is an unpublished typed transcript. Parts were published in Zachary Cope, 'Extracts from the diary of Thomas Laycock, chiefly written when he was a medical student 1833-5', Med. Hist., 1965, 11: 169-76. 


\section{Introduction}

\section{"I have entered on the race of life" (J, 35)}

The Medical School of London University was about to begin its sixth session when Laycock enrolled in $1833 .{ }^{10}$ On 1 October, Dr Robert E. Grant gave the customary introductory address on the study of medicine. ${ }^{11}$ It was not the occasion for Grant to mention the motley crew of marine invertebrates he and the young Charles Darwin had collected at the fishing village of Prestonpans near Edinburgh several years earlier, although he did touch on the general importance of comparative anatomy to the medical curriculum. ${ }^{12}$ Instead, he took a broader view and spoke eloquently upon the various mental accomplishments necessary for medical men, and passionately upon the need for the profession to reform itself in keeping with the "liberal and tolerant principles of the age". ${ }^{13}$ Thomas Wakley, the editor of the Lancet, loved it. ${ }^{14}$ So did Laycock, as he sat uncomfortably among the audience in the Botanical Lecture Theatre, still sore after travelling down on the Highflyer coach from Yorkshire six days earlier (J, 6). His body may have been numbed, but the entries in the nascent 'Journal' already indicate that "quizzing", incessantly active quality of mind by which his own students were to remember him a lifetime later.

Laycock spent three sessions at the University between $1833-35 .{ }^{15}$ Like the majority of his fellow students, he wanted to pass the examinations of the Royal College of Surgeons in London and the Worshipful Society of Apothecaries and then set up in practice. During the 1820s and 1830s, the MRCS and LSA were increasingly accepted as the conventional qualifications of respectable English provincial general practitioners. ${ }^{16}$ In the period prior to the Medical Act of 1858 , they gave an indication-no more-of professional training and helped distinguish qualified from unqualified practitioners. The latter, however, still practised with impunity beforehand and could do so afterwards, provided they did not lay false claims to medical qualifications. ${ }^{17}$

The requirements of both institutions were considerable. Prior to examination, evidence of attendance at specified numbers of lectures on anatomy and physiology (including practical dissection), on surgery, medicine, midwifery, chemistry, botany and materia medica, as well as a course based on the surgical practice of a recognised hospital were

${ }^{10}$ H. Hale Bellot, University College London 1826-1926, University of London Press, 1929, pp. 143-69; Pauline M. H. Mazumdar, 'Anatomical physiology and the reform of medical education: London, 1825-1835', Bull. Hist. Med., 1983, 57: 230-46; Adrian Desmond, The politics of evolution: morphology, medicine and reform in radical London, University of Chicago Press, 1989, pp. 33-4.

" Robert E. Grant, On the study of medicine: being an introductory address delivered at the opening of the medical school of the University of London, October 1st, 1833, London, John Taylor, 1833.

12 Ibid., pp. 8-10; Adrian Desmond and James Moore, Darwin, London, Michael Joseph, 1991, pp. 33-44, and Desmond, op. cit., note 10 above, pp. 107-10.

${ }_{13}$ Grant, op. cit., note 11 above, p. 5.

${ }_{11}^{14}$ Lancet, 1833-4, i: 73; see also Desmond, op. cit., note 10 above, pp.107-10.

${ }^{15}$ Professors' Fees Books, UCL MS. The courses attended were: anatomy (Jones Quain), practical anatomy (Richard Quain), materia medica (Anthony Todd Thomson), chemistry (Edward Turner), surgery (Samuel Cooper), practice of medicine (John Elliotson), comparative anatomy (Robert E. Grant), botany (John Lindley) [1833-4]; anatomy, practical anatomy, practice of medicine, surgery [1834-5]; anatomy, practical anatomy, surgery [1835-6].

${ }_{16}$ Susan C. Lawrence, 'Private enterprise and public interests: medical education and the Apothecary's Act 1780-1825', in Roger French and Andrew Wear (eds), British medicine in an age of reform, London, Routledge, 1991 , pp. 45-73, on p. 47.

17 Loudon, op. cit., note 7 above, pp. 297-301; Waddington, op. cit., note 7 above, pp. 143-8. 


\section{Michael Barfoot}

required by the College of Surgeons. However, the courses available at the University were specifically geared to meet all but the practical requirements associated with hospital surgical practice. University College Hospital had not yet been completed and Laycock became a pupil at the nearby Middlesex. During a short twelve week visit to Paris in the summer of 1834 , he took further classes in clinical medicine, clinical surgery, operative surgery, practical midwifery and uterine pathology, studying with Louis, Velpeau, Manec, and Halmagrad (A, 75, n 45). Laycock eventually passed his exams at the College of Surgeons on 7 May $1835(\mathrm{~J}, 130-1) .^{18}$

The Society of Apothecaries- "Rhubarb Hall" to those who satirised its pretensions after the 1815 Act-required all the preceding academic subject requirements. ${ }^{19}$ It also demanded additional evidence of attending lectures on forensic medicine, or medical jurisprudence as it was usually called at this time, which was also available at University College. The Apothecaries allowed dispensary practice to be substituted for attending the physicians of a recognised hospital. Accordingly, Laycock enrolled in the Westminster General Dispensary for fourteen months before taking his licentiateship. ${ }^{20}$ The dovetailing between the Medical School, the College of Surgeons and the Society of Apothecaries was probably a major factor in determining Laycock's attendance there rather than at Edinburgh, the only other metropolitan university available to him as a dissenter. Certainly, he must have felt vindicated in his choice when, in the same introductory address, Grant remarked:

The University of Edinburgh, so long the Athenæum of Europe, when in its glory, in the time of the Blacks, the Cullens, the Monros, the Gregorys, the Playfairs, the Leslies, consisted, as some here may remember, chiefly of an unseemly aggregate of ancient cottages, where the light of genius shone brightest in obscurity and unadorned; and in proportion as its palace has risen, that University has sunk. ${ }^{21}$

The only non-qualifying course Laycock seems to have attended at the University Medical School was Grant's own in comparative anatomy. These lectures and others given by John Elliotson, Professor of the Practice of Medicine, were probably the most enduring intellectual influences upon him at this time. Sir Charles Bell and Marshall Hall were also important, as no doubt were the lectures and writings of a host of other figures, British and foreign, significant and inconsequential, whose ideas were regularly washed up like so much medical flotsam and jetsam onto the weekly pages of the Lancet and the London Medical Gazette. ${ }^{22}$ However, the results of Laycock's medical beachcombing did not become apparent until he commenced publishing his own articles and books several years later.

${ }^{18}$ Examinations Books, Royal College of Surgeons of England Library MS.

${ }^{19}$ Lancet, 1835-6, i: ii; S. W. F. Holloway, 'The Apothecaries' Act of 1815: a reinterpretation', Med. Hist., 1966, 10: 107-29, 221-36.

${ }^{20}$ Society of Apothecaries Examiners' Books, in Guildhall Library MS 8241/7. Laycock passed on 19 November 1835. See Laycock to Edwin Chadwick, 13 March [1843], Chadwick Papers, in UCL MS 1197. On the general role of the dispensaries, see I. S. L. Loudon, 'The origins and growth of the dispensary movement in England', Bull. Hist. Med., 1981, 55: 322-42; Lawrence, op. cit., note 16 above, pp. 59-63.

${ }^{21}$ Grant, op. cit., note 11 above, p. 19.

${ }^{22}$ Grant's and Elliotson's lectures were extensively printed in the Lancet during the early 1830s. On the role of medical journals during this period, see W. F. Bynum, Stephen Lock and Roy Porter (eds), Medical journals and medical knowledge: historical essays, London, Routledge, 1992. 
“Must I follow my profession in York?" (J, 157)

When Laycock asked himself this question in the 'Journal' on 26 February 1837, it was already partly rhetorical. More accurately, it referred to whether he would continue to practise there, as he had been House Apothecary to York County Hospital for over a year (J, 147). He got the job as the result of what Wakley's Lancet regularly denounced as a "job", or through private interest exerted from within. The lever which moved the comfortable world of the Hospital's Governors took the form of his mother's brother, Alderman Robert Cattle, the man who had also paid his nephew's coach fare to London three years earlier $(\mathrm{J}, 2)$. The influence of this Tory aedile probably made the difference in a close election which Laycock won by fifty-nine votes to fifty-two. ${ }^{23}$ Later, he quarrelled with his uncle and was disinherited by him (J, 226; A, 92). He also fell out with his uncle's friend and colleague, George Hudson, the "Railway King", Lord Mayor and later an influential Tory MP. ${ }^{24}$ Fortunately, this occurred after Hudson helped him become a Visiting Physician to York Dispensary in $1842 .{ }^{25}$ During the interval, Laycock had resigned his hospital post after three years service, graduated MD at the University of Göttingen and become an extra urbem Licentiate of the Royal College of Physicians. ${ }^{26}$ Then he settled down to practise medicine in the same city he described as "not a very improving place", with many "opponents in the field", and where there were "numerous sectarian and political parties; a vast [amount] of petty scandal, a deal of pride and not a little poverty" (J, 157).

Laycock may have been critical of York as a place to live, nevertheless medical institutions were relatively well represented there. Besides the County Hospital and the Dispensary, it had a Lunatic Asylum (1777), an Institution for Diseases of the Eye (1831) and various other dispensaries, lying-in institutions and private asylums, as well as a Poor Law Medical Service (1834). ${ }^{27}$ From 1838 there was a small but active Medical School which made use of many of the nearby institutions for instruction in addition to having a small teaching museum of its own. ${ }^{28}$ Laycock lectured on the theory and practice of physic under its auspices from 1846-55. A relatively small group of practitioners monopolised most of the institutional and teaching positions available, using what advantages public

${ }^{23}$ York County Hospital, General Court Minute Book, 1820-66, 16 February 1836, York Health Trust Archives MS. See also York Courant, 18 February 1836; Yorkshire Gazette, 20 February 1836.

${ }^{24}$ See Richard S. Lambert, The railway king 1800-1871: a study of George Hudson and the business morals of his time, London, Allen and Unwin, 1949.

${ }^{25}$ The minutes of the Dispensary's directors have not survived for Laycock's period of office, but see Oswald Allen, History of the York Dispensary, York, R. Pickering, 1845, pp. 96-7. Laycock was elected on 24 March 1842. See also Yorkshire Gazette, 26 March 1842. For a recent history, see Katherine A. Webb, "One of the most useful charities in the city": York Dispensary 1788-1988, University of York, 1988.

${ }^{26}$ Papers relating to Laycock's graduation at the Unversitätsarchiv, Georg-August-Universität, Göttingen, 11-19 July 1839; Annals [of examination meetings], vol. 23, pp. 154-5, Royal College of Physicians of London Library MS. The entry for 25 February 1842 confirms that Laycock had an MD from "the Univ ${ }^{y}$ of Hanover" [sic], but it also states that he had certificates of study at Edinburgh as well as London, York and Paris. This contradicts Laycock's statement that he did not visit Edinburgh until $1848(\mathrm{~A}, 57)$ and is almost certainly an error.

${ }^{27}$ Webb, op. cit., note 25 above, pp. 14-15.

28 J. H. Wetherill, 'The York Medical School', Med. Hist., 1961, 5: 253-69; A. D. Orange, Philosophers and provincials: the Yorkshire Philosophical Society from 1822 to 1844, York, Yorkshire Philosophical Society, 1973. See also 'An introductory lecture, delivered, October 1st, 1846, at the opening of the York Medical School', Lond. med. Gaz., 1846, 3: 613-15, on p. 615. 


\section{Michael Barfoot}

office and lecturing might give to enhance their private practices. It is difficult to state with accuracy the numbers of qualified medical men in York during the 1840 s to mid-50s, when the population was around 50,000, and very little is known about the unqualified practitioners who competed with them. ${ }^{29}$ However, it is likely that York had too many medical men in relation to the proportion of the population able to pay for their services. ${ }^{30}$

In May 1849, twenty of York's qualified practitioners, including Laycock, sent a petition to Sir George Grey, the Home Secretary. ${ }^{31}$ The signatories complained that the agenda for medical reform was being set by metropolitan physicians and surgeons, when it was evident that "the marked distinction which exist[ed] between the different grades of the Profession in London ha[d] no existence in the country". In particular, they pointed out that the hospital surgeon of the provinces was not a pure surgeon, as in London, but rather a general practitioner "practising all branches and with no superiority other than merit or accident". By this time, the old divisions between physician, surgeon and apothecary had long given way in both metropolis and province. But in London, a distinction between the consulting physician or surgeon and the general practitioner had re-emerged, although on a strictly limited basis. In York, even this two-tier form of the division of medical labour was largely unsustainable, despite the apparent abundance of medical institutions. MDs, MRCSs and LSAs were really all GPs and this point is well illustrated by Laycock's own circumstances. While he was a resident apothecary in York County Hospital, his private practice outside the institution was that of a GP. After he took his MD and was Physician to York Dispensary he remained one, noting in the 'Journal' that over fifty per cent of his income in the first half of 1842 ( $£ 118)$ had come from surgical cases $(\mathrm{J}, 223){ }^{32}$ Even towards the end of his period at York when his reputation as a teacher was increasing, when his practice had grown considerably and he was frequently called into consultation by practitioners in and around York, he was still the trusted "medical friend" of many a neighbourhood family. ${ }^{33}$

One advantage Laycock saw in obtaining the Edinburgh chair was to escape from what he later described as the petty miseries "inflicted on him by the envy and hatred of professional rivals" (A, 54). The individualistic, competitive ethic of nineteenth-century British society, coupled with the extreme crowdedness of the York medical marketplace,

\footnotetext{
${ }^{29}$ See Anon., Letters to Editor on unqualified practitioners in Yorkshire, 19 April 1838 and 7 November 1844, Lancet, 1838-9, ii: $238-9 ; 1844$, ii: $290-1$. The first was probably penned by Laycock. He explicitly denied writing the latter.

${ }^{30}$ Webb, op. cit., note 25 above, has derived estimates from local trade directories and annual issues of the Medical directory. These show that in 1843 the numbers of qualified medical men had increased to 10 physicians and 39 surgeons. For two neighbouring towns, see Hilary Marland, Medicine and society in Wakefield and Huddersfield, Cambridge University Press, 1978, especially p. 235. For a wider discussion of overcrowding in the profession, see Loudon, op. cit., note 7 above, pp. 208-27; Waddington, op. cit., note 7 above, pp. $139-42$.

31 Untitled protest dated 21 May 1849, Records of the Lord Advocate's Department, in SRO MS AD58/155.

32 See Yorkshire Gazette, 1 April 1843, which recounts how Laycock fell off his horse on the way to visit a patient, badly gashing his scalp. Such accidents were a fairly common occurrence among GPs who travelled long distances on their rounds.

${ }^{33}$ Little is known about Laycock's practice in York, especially in his later years there. However, see Yorkshire Gazette, 15 March 1856, where there is an advertisement describing his house and its contents and offering them for sale or rent, which suggests his earnings had increased considerably. Given his interest in female hysteria, it would be interesting to know if, like the majority his fellow GPs at the time, his practice had an obstetric component.
} 


\section{Introduction}

made intra-professional conflict inevitable. Laycock may have been an unknown in London, but in York he was an alderman's nephew, a "supporter of the Tory party in politics" (J, 227) and a man who dined at the home of the Railway King (J, 152; A, 83). ${ }^{34}$ By itself, this configuration would have made the Whigs on York Town Council his natural opponents and placed him in direct competition with their own favoured medical advisors. However, the interaction between political and medical culture is rarely straightforward, and it is important to note it was the Whigs on the Council who proposed a vote of thanks for work Laycock carried out later in relation to the Health of Towns Commission (A, 82, n 61). ${ }^{35}$ His most immediate problem as a young practitioner lay less with the shape of local party politics and more in his immediate professional relations with the hierarchy of senior medical men who dominated the York Medical Society (1834) and the Provincial Medical and Surgical Association (1832).

Laycock was elected to the York Medical Society in 1839, shortly after his return from Göttingen. ${ }^{36}$ He read a paper on aspects of nervous disease and, along with other members, advised how to record causes of death in returns which the Superintendent Registrar of York was required to forward to the recently founded Register General's Office. ${ }^{37}$ All seemed to be going well until October 1840, when he published an article critical of the Medical Society's proceedings in the Dublin Medical Press (A, 54) ${ }^{38}$ Senior members protested and resigned, including Dr Thomas Simpson, one of the founders of the Medical School and perhaps the most prominent and influential practitioner in York at this time. Laycock offered his own resignation. It was accepted and Simpson was reelected, but the episode made Simpson into a life-long covert enemy. ${ }^{39}$

One of the first documents inserted by Laycock into the 'Account' is a record of a conversation he had with Thomas Simpson some fourteen years later (A, 54, n 3). It took place two months after he failed to be appointed Physician to York County Hospital (A, 61) and occurred immediately after another unsuccessful attempt to re-elect him to the

\footnotetext{
${ }^{34}$ Laycock depended upon old-fashioned shire Tories like Hudson and Cattle for patronage and advancement in York, where becoming a Conservative was probably a necessity for him. Nevertheless, it is unlikely he entirely shared their political views. Laycock seems instead to have been an admirer of Robert Peel who is mentioned approvingly in relation to chartership of the University of London in 1835 (J, 119). Later in Medical observation, lst ed., p. 12 (see p. xii above), he spoke admiringly of him as "the physician of the sick commonwealth".

${ }^{35}$ The circumstances of his appointment as Secretary to the York Health of Towns Committee and Hudson's role in it are recounted in the Yorkshire Gazette, 25 November 1843. Laycock's report was subsequently published in First report of the commissioners for inquiring into the state of large towns and populous districts, London, William Clowes for HMSO, 1844 (in Reports from commissioners, vol. 17), Appendix, pp. 93-129. Chadwick appears to have influenced, even shaped, the final form of Laycock's York report-a fact which partly explains Chadwick's subsequent enthusiasm for it (EC, p. 13; ET, pp. 65-6 [see p. xii above]). On Chadwick's wider role, see M. J. Cullen, The statistical movement in early Victorian Britain: the foundations of empirical social research, Hassocks, Harvester Press, 1975, pp. 53-64; S. E. Finer, The life and times of Sir Edwin Chadwick, London, Methuen, 1952; Roger Watson, Edwin Chadwick: Poor Law and public health, London, Longman, 1969.

${ }_{36}$ York Medical Society, Minute Book, 19 October 1839, York Medical Society Library MS (unpaginated).

${ }^{37}$ Ibid., 4 January, 1 and 5 February 1840; Thomas Laycock, 'Medical statistics of the York Registration District, for the first six months of 1840', Dubl. med. Press, 1840, 4: 165-7. On the background to registration see Cullen, op. cit., note 35 above, pp. 29-43. For Laycock's later involvement in this specific issue, see Chadwick to Laycock, 4 October 1844, 3 and 7 January, 3 February 1845, Chadwick Papers in UCL MS, 2181/5, 18, 16,17 .

${ }^{38}$ Laycock's criticisms could not be found in any of the surviving copies of the journal which I examined.

${ }^{39}$ Op. cit., note 36 above, 17 and 31 October, 14 and 29 November, and 12 December 1840 (unpaginated).
} 


\section{Michael Barfoot}

Medical Society $(A, 54)$. In the interim, he had quarrelled privately with his uncle and been disinherited $(\mathrm{J}, 226)$. He had disagreed publicly with Hudson about his work on the sanitary condition of York (A, 82, n 61) ${ }^{40}$ Besides Simpson, he had offended several other members of the York medical profession by his outspoken opinions about the internal organisation of the Provincial Medical and Surgical Association. ${ }^{41}$ Simpson persisted in viewing him as someone with a "quarrelsome temper" which had impeded his professional success and pointed out this was why Laycock had been passed over for the physicianship of the Hospital. ${ }^{42}$ This opinion stuck to the extent that it was transmitted to Edinburgh and actually used against Laycock during the canvass for the Edinburgh chair. It is important, therefore, to look more closely at its basis in fact and judgement.

It is certainly possible to read Laycock's personality in the manner of his detractors. Parts of the 'Journal' and the 'Account' read like litanies of self-justification written in response to episodes of personal conflict. While in London, he quarrelled with fellow students George Newport (J, 45-7, 60-4), George Collier (J, 18) and others (J, 30). He was black-balled by the University Medical Society (J, 69-70) and opposed by some members of staff for denouncing the chartership of London University (J, 109-10). He fell out with the Matron when he was living in the County Hospital (J, 153). His quarrels with Cattle and Hudson probably cost him the physicianship there in 1854. The York Medical Society persisted in excluding him for nearly fifteen years (A, 54). In the Lancet, he argued with Samuel Dickson, the famous "chronothermalist", rival Yorkshire practitioners, and the anonymous "Vindex". ${ }^{43}$ On several occasions he defended his claim to have "discovered" the reflex function of the brain and endeavoured to show how W. B. Carpenter's ideas about "unconscious cerebration" were derivative. ${ }^{44}$ After taking up his professorship in Edinburgh, he fought publicly with John Hughes Bennett, James Syme, Robert Christison and other prominent members of the Medical Faculty (A, 100-14). It would be perverse to disregard all this; yet it does not necessarily follow that he had a "quarrelsome temper".

${ }^{40}$ See Hansard's parliamentary debates, vol. 93 (2 June-6 July 1847), pp. 1101-2, 1282-5, for remarks by Hudson and Wakley's reply during which he read a letter by Laycock to the House. See also Laycock to Editor, in The Times, 12 July 1847. For Chadwick's interpretation of Hudson's attack, see his letter to Laycock, 7 July 1847, Chadwick Papers, in UCL MS 1197, and Laycock's reply of 9 July, ibid. The correspondence also reveals that Laycock was co-operating with Wakley in the promotion of Chadwick's work by writing anonymously about it in the Lancet.

${ }^{41}$ Laycock to Editor, 9 August 1841, in Lancet, 1840-41, ii: 722-4 and comment upon, 787-9; Laycock to Editor, 25 September 1841, ibid., 1841-2, i: 98-9. For the wider context of the dispute, see W. H. McMenemey, The life and times of Sir Charles Hastings, founder of the British Medical Association, Edinburgh, Livingstone, 1959, pp. 223-33.

42 York County Hospital Minutes, 12 September 1854 (unpaginated); Yorkshire Gazette, 16 September 1854. See also ibid., 12 August 1854, where Laycock published an address to the Hospital governors, listed his publications and reproduced a testimonial from Sir Henry Holland.

${ }^{43}$ Charles S. Bryan, 'Dr. Samuel Dickson and the spirit of chrono-thermalism', Bull. Hist. Med., 1968, 42: 24-42. For Laycock's dispute with Dickson, see Lancet, 1842-3, ii: 247-8, 392; and with Beverly R. Morriss, Laycock's colleague at the York Dispensary, see ibid., 1845, i: 103-4, 169; and with 'Vindex', ibid., 1846, i: 197-8, 399-400, 424-5, 510-11.

${ }^{44}$ For a summary see Mind and brain, 1 st ed., vol. 2, pp. 465-80 (see p. xii above); idem, 'Reflex, automatic and unconscious cerebration: a history and a criticism', J. ment. Sci., 1876, 21: 477-98, on pp. 478-98; 22: 1-17, on pp. 15-16. For the original correspondence with Carpenter, see Laycock Collection, in RCPE MS box 22, file 147. Not all writers gave priority to Carpenter. See, for example, George Henry Lewes, The physical basis of mind, London, Trübner, 1877, pp. 453-4; Léon Dumont, 'L'action réflexe cérébral Mm. Laycock, Carpenter, Luys', Rev. Sci., 1876, 10: 25-33. 


\section{Introduction}

The underlying causes of intra-professional conflict in York have already been noted and they were present in most, if not all, of Britain's cities and more populous towns. Waddington has argued that repeated public discussion of practitioner-practitioner relations is more characteristic of British medical ethics prior to 1858 than any concern to understand the reciprocal rights and duties of patient and practitioner. ${ }^{45}$ Controversy at the grass-roots level, as well as in the more cerebral sphere of medical publishing, was endemic. Laycock's adversaries Newport, Collier, and Carpenter all had their own quarrels which mirrored those besetting Laycock as an aspiring practitioner. ${ }^{46}$ The careers of Grant, Elliotson, Bell and Marshall Hall were equally controversial. ${ }^{47}$ Simpson, Syme, Bennett and other members of the Edinburgh medical community were regularly at each others throats on the page and, sometimes, even on the court benches. ${ }^{48}$

As a regular reader of the Lancet, the vituperation associated with the medical community in general, and with Edinburgh practitioners in particular, is something Laycock could scarcely have been unaware of during the 1850s and especially in the months leading up to the 1855 election. ${ }^{49}$ Inured to a lifetime of controversy, he was not naive about this modus vivendi of nineteenth-century medical life. His original observation was only that the chair would give him a means of escaping the petty jealousies and rivalries of York, not that Edinburgh was free of its share of the same troubles. Simply to dismiss him as quarrelsome by temperament without taking into account the wider context of conflict within the profession at large is not necessarily the best way to understand Laycock's predicament. A more subtle view of how his personality shaped and, in turn, was shaped by his controversies with others is required, not the least because it had a direct effect on the narrative form of the 'Account' itself.

\section{"Man is born for trouble as the sparks fly upwards" (J, 122)}

Laycock wrote more than once about the "race of life" and the need to out-distance his rivals $(\mathrm{J}, 12,35) .{ }^{50}$ Always conscious and sometimes suspicious of his own ambition, he

45 Op. cit., note 7 above, p. 159.

46 For Newport against Hall, see Lond. med. Gaz., 1837-8, i: 930-2, 985-6; Collier against Leibig, Lancet, 1841-2, ii: 888-9; 1842-3, ii: 70-1, 74; Carpenter against Hall, ibid., 1838-9, i: 581-4; 1839-40, i: 282-3.

${ }^{47}$ For Grant, see Desmond, op. cit., note 10 above, pp. 389-97. For Elliotson, see the controversies over mesmeric experiments performed on the O'Key sisters, Lancet, 1837-8, ii: 516-18, 836, 873-6; 1838-9, i: 561-2; 1840-1, i: 897-900, etc. For Bell, see Gordon Gordon-Taylor and E. W. Walls, Sir Charles Bell: his life and times, Edinburgh, E. and S. Livingstone, 1988, pp. 105-33. For Hall, see Lancet, 1846, ii: 250; 1850, ii: 120-8; Charlotte Hall, Memoirs of Marshall Hall . . . by his widow, London, Bentley, 1861.

${ }^{48}$ On the background to nineteenth-century Edinburgh medical quarrels and Syme's prominent role in them after 1840, see Robert Paterson, Memorials of the life of James Syme, Edinburgh, Edmonston and Douglas, 1874, pp. 198-209, 228-67. During the 1830s, the Lancet had an "Edinburgh Correspondent" who regularly kept readers informed on the controversies of the day. See, for example, 1833-4, i: 981; ii: $166-9,363-4,774-5$, 937-8.

49 For quarrels about the running of the Monthly Journal of Medical Science which, at various times, was edited by Syme, Simpson, Bennett and other Edinburgh University professors, see Lancet, 1850, ii: 222, 280-1, 306-7, 400-2, 431. For the dispute over a medical bill prepared by the University professors, see ibid., 1855, i: 388. In the year of Laycock's election, Syme was being sued by a local practitioner (Glover) over his conduct towards an Infirmary patient, having been sued by John Lizars a few years earlier. The intra-Faculty dispute between the homoeopathist Professor of Pathology, William Henderson, and the other medical professors also attracted a great deal of public attention around this time.

50 'Introductory lecture to York Medical School', Lond. med. Gaz., 1846, 3: 613-17, on p. 616; Introductory Lecture, Laycock Collection, in RCPE MS box 21, file 141. 


\section{Michael Barfoot}

was very aware that professional success implied one's share of detractors and that, in the eyes of the multitude, this was actually the measure of a man's fame. During controversies, public averments and denials were expected as a matter of course. The medical press, while it continued to deplore professional bickering in editorials, went on giving combatants the necessary copy to do their worst-presumably upon the principle that not to reply was tantamount to accepting a public accusation as true. There is little doubt either that Laycock associated competitiveness with a manliness of character which he admired and aspired to; nor did he shrink from what he regarded as a duty to maintain his honour and reputation.

Despite this apparently pugilistic stance, Laycock was firmly against free-for-alls. He believed controversies had very definite rules of engagement which should not be broken and strove to behave accordingly. ${ }^{51}$ More widely in his life, Laycock seems to have aspired to the high standards of character and conduct he associated with the demeanour of a true gentleman, a title he declined to apply to the man of mere wealth and position unless his manners deserved it. Always quick to condemn moral weakness in fellow students, colleagues, friends, and even family members, he was equally self-critical. Personal condemnation is a regular theme of the 'Journal', and on one notable occasion he referred to himself as "ret[urning] like a dog to [his] own vomit" (J, 180). Loss of self-control through drunkenness seems to have decanted the remark into his diary, but precisely what "debauch" occurred in its aftermath is unclear. ${ }^{52}$

This and other episodes are indicative of Laycock's compulsive tendency to "moralize" about himself, even during a rare night off at the theatre (J,40-5). He was very aware and, indeed, suspicious of his ambitious endorsement of the "race of life". At the same time, there were tensions between his aspirations to professional success and an equally strong desire to remain a moral person with a good conscience in keeping with his Methodist upbringing. The dilemma was chronic throughout Laycock's early life and it became acute when he participated in his first election for public office. After becoming House Apothecary to York County Hospital, he wrote that he had succeeded "after flattering[,] lying and electioneering in every possible way" (J, 147). Instead of feeling "promoted", he felt "degraded" and interpreted the whole episode as administering a necessary antidote to the moral poison of his overweening pride $(\mathrm{J}, 148)$.

Given that, at an earlier period, Laycock was concerned to find a way of striving professionally which left his personal integrity intact, it is perhaps significant that no analogous feelings of self-disgust are ever recorded in his description of how he won the Edinburgh election. Yet many details recorded in the 'Account' do seem to corroborate the view taken by the leader writer of the Edinburgh News that the "boundary line of propriety ha[d] been sadly overstepped" (A, 97, n 97). Laycock's only professed regret was that Simpson sent all his patients away to drive the new professor-elect around the town in an open carriage to celebrate his victory (A, 97, n 90). It might simply be that the 'Account' is a different kind of narrative from the immediate, intimate, confessional style of the 'Journal'. However, a more compelling reason is that by 1860 , Laycock seems to have

\footnotetext{
51 See, for example, 'Correspondence between Geo. Combe, Esq. Professor Reid, and Dr. Laycock on the reflex anatomy and physiology of the Brain', Lancet, 1845, ii: 231-3, 255-8, 283-4, 308-10, 347-8, 364; Combe Papers, NLS MS 7276, ff. 3-19; 7280, ff. 114-18; Sequel, 58-9.

52 The allusion is to Proverbs, 26: 11.
} 


\section{Introduction}

been able to commend his success in obtaining the professorship in a manner which appeared to leave his moral sentiments intact. Precisely how he succeeded in squaring the circle of conflicting psychological needs for both public success and personal integrity in an age known for its patronage, not to say corruption, invites further examination.

Laycock's search for a resolution of his dilemma went deeper than ideas of personal honour, decorum and gentlemanliness. Like so many of his mid-Victorian contemporaries, his conduct had a crucial religious dimension. His religious upbringing gave him a means of dealing with life's disappointments by inculcating an expectation of suffering. He was ready for setbacks to the extent that, whenever "the kiss" of success was bestowed, he anticipated "the blow" of failure soon afterwards (J, 191). Expecting the worst became a way of life. While he lived and worked in York County Hospital, a brother and a sister died of tuberculosis-related illnesses $(\mathrm{J}, 151,206,209)$. During that time, he was acutely aware of the body's mortality and he fully expected his death would be next in the family ( $\mathrm{J}$, 152). On such occasions religion could give him a higher focus and purpose through the hope of what he referred to as "futurity" (J, 170-2). When compared with the promise of a heavenly future after the Resurrection, the irritations of professional life often-though not always-appeared insignificant.

Although grateful to Methodism for the education and opportunity it gave him, Laycock had grave doubts about subscribing personally. While in London he visited the Connexion's and other chapels. On occasions he was moved by a preacher's sermon; but on the whole he despised the scenes of evangelical fervour he witnessed (J, 24-5, 30-3, 49-50). He preferred to take on the role of the curious "medico", seeing the collective hysteria of Edward Irvine's chapel meetings as phenomena more akin to mesmerism and spirit-rapping than the workings of the Holy Spirit. ${ }^{53}$ Later he came to doubt the miraculous cures recorded in the Bible on similar grounds, seeing in them the tell-tale symptoms of nervous disease (J, 213-18). Yet the secular movements of the day did not appeal to him either. Laycock was genuinely appalled when he went to Owen's Equitable Exchange Bazaar in London and heard a lecture on St Simonianism $(J, 50-4)$. While there, he saw various works "of the same infidel atheistical description" on sale to the working classes, or those he elsewhere described as London's “"buggy' Myrmidons" (J, 20). ${ }^{54}$ Any scheme of morality and social order not founded on "true religion" was anathema to him and he believed it would lead not only to conflict in society but its eventual destruction.

Caught between the secularism of the socialist St Simonians and the evangelical fervour of the Irvinites, he despaired of finding a form of religious belief which sat comfortably with his intellect and professional labours as well as with his underlying feelings. For all Laycock's speculations about how a resurrection of the dead might be brought about ( $\mathrm{J}$,

\footnotetext{
53 On Irvine, see Andrew Landale Drummond, Edward Irvine and his circle including some consideration of the "tongues" movement in the light of modern psychology, London, James Clarke, [1937], pp. 214-22, 236-70; William Jones, Biographical sketch of the Rev. Edward Irvine . . . London, John Bennett, 1835, pp. 322-80.

${ }^{54}$ On the exchange bazaars, see Frank Podmore, Robert Owen, 2 vols, London, Hutchinson, 1906, vol. 2, pp. 392-422; Eileen Yeo, 'Robert Owen and radical culture', in Sidney Pollard and John Salt (eds), Robert Owen prophet of the poor: essays in honour of the two hundredth anniversary of his birth, London, Macmillan, 1971, pp. 84-114. Laycock's visit was probably to the Bazaar at Gray's Inn Road, a building the Owenites once shared with Irvine's followers after the latter left the Regent Square Church. Although his arrangement seems to have ceased by the time he went there, Laycock's experience of both meetings on 29 December 1833 seems to have had a profound effect upon him: "I have this day witnessed the two extremes. Irvine all mysticism[,] Owen all morality, liberty, equality" (J, 54).
} 


\section{Michael Barfoot}

65-6, 163-75) and notwithstanding his awareness of how works like William Ellis's Polynesian researches could undermine the divine origins of many Christian beliefs (J, 210), he does not seem to have been temperamentally predisposed to scepticism as such. ${ }^{55}$ His particular difficulty was to find a denominational form of worship within which the transition from "quizzing" to believing could be smoothly managed: "Must I be a Papist Episcopalian, Calvinist Unitarian, mystical Swedenborgian or a socialist? or shutting my eyes, be a Wesleyan because my father was?" (J, 224).

Laycock's religious crisis occurred immediately before he went to Germany for his MD and he resolved to cut himself off from the influence of all sects and to pray for guidance (J, 225). When he returned, he had achieved at least a partial understanding of his predicament. A little later he summed it up as follows:

I have published my treatise on nervous diseases; it appeared Nov last; I have gone through the hands of the critics and with some credit ... I have written some letters on Political medicine ... I have come forward as a medical reformer. I have succeeded tolerably well in practice; I have joined the Tory party in politics. In religion I am still undecided except that I hope by the blessings of the God of my father to do good while I live. I have resolved to imitate Him as well as I am able and do something in this world so beneficial to mankind that men will not willingly let the memory of it die. Medicine may be applied comprehensively and effectually to the general good of mankind. It may improve the morals, assist in dispensing justice and in education alleviate the pressure of poverty by removing the causes of disease, spread Xtianity and British knowledge over the world. (J, 227-8)

By appreciating God manifested in Nature, he considered that the intellectual labour involved would, at the very least, gain him a "good conscience" (J, 199). Laycock also believed he should emulate God by doing His work on Earth. This latter aspect reinforced a pre-existing commitment to care for the sick poor as a reward in and for itself which he had made while a hospital apothecary $(\mathrm{J}, 188) .{ }^{56} \mathrm{He}$ remained true to it in his dispensary work, paying regular visits to the homes of the sick-poor. It also motivated his public health work on behalf of the Health of Towns Commission and while Secretary to the

\footnotetext{
55 William Ellis, Polynesian researches, during a residence of nearly six years . . , 2 vols, London, Fisher and Jackson, 1829. In view of the similarity between Jewish rites and those of the Polynesians, Laycock was worried about the divine origin of scripture. See also Andrew Carmichael, An essay on such physical considerations as are connected with man's ultimate destination, the essential constitution of superior beings; and the presumptive unity of nature, Dublin, Shaw, 1830, especially pp. 95-6, which Laycock was reading at this time $(\mathrm{J}, 9)$. Shuffling and reshuffling the biblical pack of ideas about the Resurrection during the early stages of medical studies may have been fairly common among religiously-inclined students. See, for example, Jessie Aitken Wilson, Memoir of George Wilson, Edinburgh, Edmonston and Douglas, 1860, pp. 63-5. Wilson began to study medicine in the same year as Laycock and their diary entries express strikingly similar feelings as they attended anatomical dissections, witnessed their first operations and re-thought the Resurrection in the light of new knowledge and experiences. Wilson was eventually appointed regius Professor of Technology in 1855 and both men were inducted into the Senatus on the same day. See R. D. Anderson, “What is Technology?": education through museums in the mid-nineteenth century', Br. J. Hist. Sci., 1992, 25: 169-84, on pp. 176-8.

${ }^{56}$ After being profusely thanked by a young and crippled girl beggar as she died, Laycock wrote "May such be the only remuneration I receive from the poor for professional attention. O God! Let not familiarity with misery harden my heart against the sufferings of the wretched and particularly of the pining poor" (J, 188). She had been brought to York County Hospital by George Hudson.
} 


\section{Introduction}

Statistical Section of the British Association for the Advancement of Science. ${ }^{57}$ Afterwards, he continued it as Secretary of the York Health of Towns' Association. ${ }^{58}$

By the late 1840s Laycock was still privately unimpressed by denominational Christianity. A long essay written for the British and Foreign Medico-Chirurgical Review in 1848 suggests he found a further elaboration of what he was looking for in Johann Gottlieb Fichte's On the nature of the scholar, then recently translated into English. ${ }^{59}$ In the manner of Fichte's true scholar, he argued that the cultivated physician should aim to understand more and more of the Divine Idea lying behind appearances and so become increasingly possessed by a higher and more spiritual life. This growth of spiritual being was to be achieved by doing active work on Earth in order both to enlarge the sphere of the Divine Idea itself and to accrue enough spiritual dignity in this world to determine one's position in the next. Laycock wrote that "the path of duty lies to the professional man, in the exercise of his profession with Godlikeness, and with integrity and love" ${ }^{60}$ Fichte gave a transcendentalist cast to an ethical scene which Laycock had already glimpsed in the Bible, most notably in Paul's Letters to the Corinthians and the Wisdom of Solomon, both of which he referred to in the 'Journal' (J, 51, 166-74, 201-2). There was also something of the hero and hero worship in the whole approach:

Some medical Fichte may arise and glad the ears and hearts of listening thousands; some bravely and eloquently wise man may appear in the field of medical culture, and head the crowd of young and enthusiastic aspirants to moral glory; and so with them, both the first and second part of the inscription on Fichte's funeral obelisk will be fulfilled:

"THE TEACHERS SHALL SHINE AS THE BRIGHTNESS OF THE FIRMAMENT; AND THEY THAT TURN MANY TO RIGHTEOUSNESS AS THE STARS FOR EVER AND EVER".61

\footnotetext{
${ }^{57}$ Chadwick wrote a letter to the Home Secretary on the question of death registration which Laycock then sent under his own name in his capacity as B.A.A.S. Statistical Secretary. See Chadwick to Laycock, 3 January 1845; Laycock to Sir James Graham [1845], Chadwick Papers in UCL MS 2181/8. When he received $£ 40$ from the B.A.A.S. to study the sanitary condition of York, it was Chadwick and W. P. Alison's names which also appeared alongside his own on the grant form. See Jack Morrell and Arnold Thackray, Gentlemen of science: early years of the British Association for the Advancement of Science, Oxford, Clarendon Press, 1981, p. 344, and plate 24. Laycock reciprocated by reviewing Chadwick's publications favourably. See Laycock to Chadwick, Chadwick Papers, in UCL MS 1197; idem, 'The medical police of the United Kingdom', West. Rev., 1846, 45: 56-88, on pp. 67-70,81.

58 For Laycock's involvement in various civic improvement schemes about water and sewerage, see Chadwick to Laycock 8 August, 18 and 19 September, 1845, Chadwick Papers, in UCL MS 2181/12, 1197 and $2181 / 11$ and 1197. See also Laycock's Report of the committee on the smoke nuisance, with evidence as to the causes of the nuisance and of the entire practicability and economy of prevention, York, W. Sotheran for the York Health of Towns Association, 1852.

59 Johann Gottlieb Fichte, On the nature of the scholar and its manifestations, trans. William Smith, with a memoir of the author, London, J. Chapman, 1845. In the same review, Laycock also discussed the newly published rules of the Manchester Medico-Ethical Association, a work on medical missionaries by D. J. Macgowan, and a natural theological account of the pre-Adamite earth (John Harris).

${ }^{60}$ See 'Medical ethics', Br. for. med. chir. Rev., 1848, 2: 1-30, on p. 13. For a contemporary interpretation of the significance of Fichte, see George Henry Lewes, The biographical history of philosophy, from its origin in Greece down to the present day, Library ed., London, J. W. Parker, 1857, pp. 566-90.

${ }^{61} \mathrm{Op}$. cit., note 60 above, p. 26. The quotation is from Daniel, 12: 3. Laycock probably first became acquainted with Fichte's ideas by reading the popularisations of Coleridge and Carlyle, and then through the originals as his knowledge of German steadily improved. See Thomas Carlyle, 'The hero as man of letters: Johnson, Rousseau, Burns', in On heroes, hero-worship, and the heroic in history . . . London, James Fraser,
} 


\section{Michael Barfoot}

In his review, Laycock considered that "the physician's proper study is MAN in every possible relation" ${ }^{62} \mathrm{He}$ even used the term "science of human nature" in the manner of David Hume and his successors, but metaphysics had now given way to medicine as the means by which man's improvement would be delivered; and scepticism, however mitigated, was to be replaced by a broadly latitudinarian Christian synthesis of morality and philosophical truth. ${ }^{63}$

By the 1850s, Laycock had a fully articulated religious philosophy which gave order and purpose to his various activities as a practitioner, teacher and author. He wrote:

In religion I seek God more and more in the phenomena of visible things and finding Him there commune with Him in my own heart and hope I shall wake up in His own likeness. Less and less I esteem the established formulae of sects of all kinds, and look upon them rather as imperfect agencies adapted to an imperfect state of society than that which the Great God of Heaven and Earth has determined upon and which will be in due time. Not the less do I desire to be useful and to minister to God's Glory, than aforetime, but I feel more and more that this present life is but a preparation for eternity and as years roll on I feel the absolute necessity of doing that which my hand findeth to do, with all my might. Amen. (J, 237-8)

This personal creed holds the key to how the various religious, professional, moral and personal dimensions of his life became integrated into a consistent cosmology. Having found his own higher purpose, Laycock quite literally re-wrote it back into Nature where it could be read as a prophesy of the imminent arrival of himself as the medical Fichte. Later, against advice, he decided to republish his 1848 review in the weeks leading up to the Edinburgh election. It was retitled Religio medicorum and he dedicated it to his recently deceased mother $(\mathrm{A}, 83, \mathrm{n} 65) .{ }^{64}$ What was seen as a cheap election trick by his opponents gave Laycock, the medical Fichte, no qualms. He probably believed he could do more for medicine as Professor of the Practice of Physic at Edinburgh University; therefore the moral end justified the political means. Applying his principle that work as a physician-even a physician conducting an election campaign-was also God's work, he had found a way of justifying his ambition in terms of the imperatives of his transcendental religion.

The inner calm produced by this absolute and apparently unimpeachable form of selfjustification gave him a distinctive perspective from which to write a history of his own election. Mid-way between getting the chair and beginning the history of the campaign in 1860 , his moral rectitude and conduct had received another dramatic confirmation in the

1841, pp. 249-315, on pp. 252-4; idem, 'State of German literature', Edin. Rev., 1827, 46: 304-51, on pp. 329-31. Samuel Taylor Coleridge, Biographia literaria; or biographical sketches of my literary life and opinions, 2 vols, London, Rest Fenner, 1817, vol. 1, pp. 147-8, 151.

${ }^{62}$ Op. cit., note 60 above, p. 3.

${ }^{63}$ This theme is evident throughout Mind and brain. For a succinct statement, see also Laycock's The social and political relations of drunkenness: two lectures, Edinburgh, Myles Macphail, 1857, especially his prefatory 'Dedication to the students at Edinburgh University', where he wrote: "When a similar conflict of opinion took place in the last century, the University of Edinburgh rallied round the tricolour flag of religion, science, and common sense,-the flag of Scottish philosophy. . . Let us raise the Scottish Tricolour" (unpaginated).

${ }^{64}$ Religio medicorum: a critical essay on medical ethics, Edinburgh, Adam and Charles Black, 1855. Apart from a footnote on the first page giving details of its previous publication, the text and pagination are unchanged. 


\section{Introduction}

controversy about teaching clinical medicine at the Edinburgh Royal Infirmary (A, 100-4). Having laid documentary evidence before the public supporting his side of the conflict which seems to have won the day, he embarked upon another narrative of how he was victorious in the professorial race of 1855 . The 'Account' has an air of frank openness about events surrounding the election which seems to complement his use of original documents as evidence to create an over-all impression of objectivity. It was written with a clean conscience, a deceptive state of mind which blinded Laycock to the fact that the more he describes what happened, the more his complicity in events becomes apparent.

\section{"Desirous of power over the minds of men" $(A, 53)$}

The various stages in Laycock's career from shop-boy to respected provincial physician fall into a distinctive pattern which is entirely recognisable for the time: apprenticeship, further medical study, a junior post resident in a hospital, general practice, further qualification as a physician, formal accreditation to a respected medical institution, a corresponding increase in practice which now included a lucrative consulting component, all of which leading to reputation and reasonable financial security. It was an ideal progression which many nineteenth-century medical men aspired to but relatively few attained. Some of those who did also taught and published along the way, but this was by no means essential to success. Indeed, lecturing and authorship had drawbacks as well as advantages. The manners of the classroom were rarely those of the examination room and a man could be typecast as a good lecturer yet a poor practitioner. Too much speculation in print on matters physiological and pathological could suggest a lack of those practical skills upon which practice - especially general practice-was believed to depend. Despite the risks, Laycock was eager to see himself in print.

Various early schemes for a student journal and a text-book got him no further than the London office of Mr John Churchill, the well-known medical publisher. However, a study of the acid and alkaline reactions of the saliva observed in forty-eight patients from York County Hospital appeared in 1837 , followed by descriptions of particular cases he had attended in York County Hospital. ${ }^{65}$ These modest contributions in the London Medical Gazette were very safe beginnings, based as they were on empirical observation and careful experimental investigation. Laycock's method of presentation was exactly that advised by the editor of the first volume of Medical essays and observations (1732), arguably Britain's first exclusively medical journal. ${ }^{66}$ Facts not hypotheses; eye-witness accounts not hearsay; description not denunciation, these methodological components which made up the original formula were still the basic ingredients of medical literature over a century later.

Within two years, however, the style of Laycock's articles began to change, and began to reflect his own preferred style of thought, or what he described in the 'Journal' as a "power of generalizing or assimilating" ideas gathered not "as the ant but the bee" (J, 160-1). Colin Maclaurin, the eighteenth-century Scottish mathematician, used this

\footnotetext{
65 'Observations of the saliva upon red and blue litmus, and turmeric paper', Lond. med. Gaz., 1837-8, i: 43-50; 'Cases of pulmonary affection: with remarks', ibid., 456-60.

${ }_{66}$ Medical essays and observations revised and published by a society in Edinburgh, 5 vols, Edinburgh, G. Hamilton, 1733-44, vol. 1 (1733), pp. v-xxi.
} 
metaphor to summarise the Baconian view that while the empiricist ant collects discrete facts, and the spider spins theories by the webful, the busy bee unites both to produce useful knowledge which is truly scientific. ${ }^{67}$ While still appearing to rely upon the standard case history presentation, Laycock gradually shifted from discussing those patients he had observed in the hospital to reviewing cases culled from other authors, past and present. Moreover, he used them to theorise about the physiological and pathological relations of hysteria, that cui in plures jus est transire figuras of eighteenth-, nineteenthand even twentieth-century medicine, in a series of articles for the Edinburgh Medical Journal. ${ }^{68}$ Such hysterical buzzings certainly resonated among his medical examiners at Göttingen. On the basis of these contributions they awarded him his MD summa cum lauda in 1839.

A year later, Laycock reorganised and extended the original papers to produce his first book. ${ }^{69}$ In the preface of the Treatise, he outlined a manifesto for all his future work in medicine. This was done in terms of the method, purpose and value of the approach he would employ, rather than the precise topics he wanted to work on.

I have often thought that treatises on the practice of Medicine professing to be free from theory, and to contain nothing more than a description of diseases, and the methods of treatment, are of questionable utility. The condensed style in which they are usually written, admits of no detailed exposition of the principles laid down, or of the facts from which those principles are deduced. The writer, consequently, appears to dictate, rather than to state an argument; to be the occupant of a professorial chair, than a fireside companion. The interest which physiology might give to the subject is lost sight of; and thus the work is dry and uninteresting, and never studied. (TND, vii.)

Laycock contrasted this kind of "practical medicine" with what he termed "scientific medicine" (TND, viii). He believed scientific medicine had more immediate practical usefulness and prospective benefit than its alternative because it implied an enlarged sphere of activity for the physician where he could be more "godlike" in his work for the good of mankind. He endorsed this wider conception while rejecting others which strongly identified scientific medicine with specific techniques, such as those used in physical, chemical and microscopic diagnosis, or with a particular methodology. This stance informed Laycock's attitude towards diagnostic aids, such as the stethoscope, ophthalmoscope and other instruments, and to the use of numerical methods in medical

\footnotetext{
${ }^{67}$ Colin Maclaurin, An account of Sir Isaac Newton's philosophical discoveries, Edinburgh, printed for the author's children, 1748, p. 58. As a student trained in one of the North's dissenting academies, this would have been an obvious source for Laycock to familiarise himself with the methodological views of Bacon as well as Newton.

${ }^{68}$ James Gregory first used this phrase to describe the aether in Conspectus medicinae theoreticae ad usum academicum, 2 vols, Edinburgi, Gulielmum Creech, 1782, vol. 1 (originally published 1778), p. 64. 'A selection of cases presenting aggravated and irregular forms of hysteria; and an analysis of their phenomena: no. 1 hysterical ishuria', Edinb. med. surg. J., 1838, 49: 78-109, 221; 'No. 2. containing 1. hysterical haemorrhages; 2. hysterical nervous affections', ibid., 436-61; 1838, 50: 24-66, 302-56; 'Analytical essay on irregular and aggravated forms of hysteria', ibid., 1839, 52: 43-86. For a recent overview of the historical literature on hysteria, see Mark S. Micale, 'Hysteria and its historiography: the future perspective', Hist. Psych., 1990, 1: 33-124 (Laycock on pp. 43, 85, 94, 302 and 311).

${ }^{69}$ Obituaries of Laycock emphasised the importance of the Treatise (see p. xii above) for subsequent studies of hysteria. For reviews of it, see Br. for. med. Rev., 1841, 12: 60-77; Dubl. med. Press, 1841, 4: 395-6; Lancet, 1840-1, ii: $197-8$.
} 


\section{Introduction}

research when he taught clinical medicine at the York Medical School from 1846, and at the Royal Infirmary of Edinburgh after $1856 .^{70}$ Thus it was Laycock's medical Fichteanism which dictated the agenda of what was to count as scientific medicine; the moral end determined the diagnostic means.

Laycock's Treatise asserted the importance of the "ovarian influence" and criticised older theories of hysteria based on "strangulation of the uterus" (TND, 1). He also argued that practitioners were regularly mistaking cases of hysteria for organic disease, often with disastrous consequences for the patient (TND, 20-43). Besides the fireside method, the other notable general feature of his book is the use of a comparative anatomical approach to the "special physiology" of the female reproductive organs.

If we would fully investigate the relations of the sexual organs of woman to the phenomena of disease, we cannot confine ourselves simply to women per se, but must extend our inquiries, as far as practicable, into the whole series of animal life, including man himself. (TND, 10.)

In keeping with many of his contemporaries, Laycock considered that the reproductive organs influenced the whole animal economy and not just the nervous system. This was demonstrated by the fact that "the final cause of all vital action is the reproduction of the species" (TND, 9). In the higher animals, including humans, the reproductive organs shaped psychological attributes associated with reproduction, such as the desire for sexual congress and the love of offspring. Here and elsewhere in his writings, Laycock's commitment to final causes, the "whole chain of being", and what he referred to throughout as "developement" [sic] led him to argue that the physiology of body and the psychology of mind were intimately connected in the human species. He had learned Grant's early lessons well, and now broadened his knowledge of continental comparative anatomy tradition as far as his circumstances working in York County Hospital and the availability of books would permit. The subject of hysteria was an obvious choice. Apart from having easy access to clinical subjects, it gave him an opportunity to draw together what he had learned about comparative anatomy and the new researches on the nervous system by Bell, Hall, Samuel Solly and others, and to apply both sets of intellectual resources to an important and topical medical problem. ${ }^{71}$

In places, the list of works cited in the Treatise reads like a roll-call of prominent London teachers, whether at the University, the hospitals or other medical schools (TND, xxvii-xxxii). In his 'Journal', Laycock referred to such men as the "Master minds of the Metropolis" (J, 158). Inspired by his developing sense of a personal vocation in medicine, he engaged with their ideas, strove to emulate them as a medical author and, eventually, he

\footnotetext{
${ }^{70}$ Saundby, op. cit., note 3 above, p. 1054, and others, implied Laycock was an opponent of physical, chemical and microscopic diagnosis, but other evidence suggests he was in fact highly skilled in such methods. See 'A lecture on clinical observation; its value and nature, and the mode and means of practising it, delivered at the York Medical School', Lond. med. Gaz., 1846, 3: 141-8; Laycock Collection, in RCPE MS box 2, file 13; box 14, file 97; and Laycock's Royal Infirmary clinical ward case books in LHSC MS LHB1/129. Laycock's broader discussions about method suggest he only opposed these forms of diagnosis when they were at the expense of other approaches which could be more timeous and therefore lessen patient suffering. See Medical observation, 1st ed., pp. 50-3. For his attitude to numerical methods, see ibid., pp. 149-77.

${ }^{71}$ L. S. Jacyna, 'Principles of general physiology: the comparative dimension to British neuroscience in the 1830s and 1840s', Stud. Hist. Biol., 1984, 7: 47-92.
} 


\section{Michael Barfoot}

competed with them for "power over the minds of men" (A, 53). By the act of writing he was able to pass beyond the narrow confines of professional life in York and participate on more equal terms in the wider intellectual culture of medicine. Through his work on the nervous diseases of women he went on to make the acquaintances of J. Y. Simpson, Henry Holland, James Clark, and John Forbes. ${ }^{72}$ The latter edited the British and foreign medical Review, perhaps the most serious heavyweight contender among the journals of the day. ${ }^{73}$ Laycock was quickly added to the small team of reviewers and he continued to publish in its successor, the British and Foreign Medico-Chirurgical Review after Forbes gave up the editorship.

Before 1853 all reviews in the British and Foreign were published anonymously. This gave Laycock the opportunity to indulge his early love of medical journalism to the full and write with freedom about the men he met regularly at the British Association and elsewhere. His pieces were often imaginatively composed in the spirit of good humoured, hearty criticism, a style he was rarely able to bring to bear in his direct social relations with authors themselves. ${ }^{74}$ All his earlier literary productions, anonymous and acknowledged, were charged with a considerable amount of feeling and drew heavily upon his own personal experiences.

Work on "proleptics", or vital periodicity, was as much inspired by Laycock's observation of the regular intervals of birth and death among members of his own family as it was by an intellectual appreciation of the inexorability of natural laws governing health, disease and the environment $(\mathrm{J}, 206) .{ }^{75}$ His clinical interest in consumption also had deep roots in family experience. In various forms the disease seems to have killed most of his brothers and sisters; he was a sufferer in middle life (A, 102), and his final illness in 1876 was associated with a relapse. His portrait of the dissimulating, hysterical female was underwritten by his own observations of evangelical chapel fever as well as reading about Elliotson's dealings with the O'Key sisters at University College Hospital. ${ }^{76}$ It also resonated with a low personal opinion of young women in general which often found expression in 'Journal' entries made during his twenties and early thirties. This was

\footnotetext{
72 On Holland, see ""More fashionable than scientific": Sir Henry Holland . . ', Pract., 1973, 211: 548-5. On Clark and Forbes, see Alexander Allan Cormack, Two royal physicians: Sir James Clark, Bart., 1788-1870, Sir John Forbes 1787-1861: schoolmates at Fordyce Academy, Banff, Banffshire Journal, n.d. On Forbes, see Anon., 'Sir John Forbes, M.D., D.C.L., F.R.S.', Br. for. med. chir. Rev., 1862, 29: 271-82.

73 John Forbes, 'Postscript to no. xlviii of the British and Foreign Medical Review', Br. for. med. Rev., 1847, 24: 585-98.

${ }^{74}$ For example, see 'The public hygiene of Great Britain', Br. for. med. Rev., 1844, 18: 492-513, on pp. 512-13, where he teased Alison and Southwood Smith for their preferred explanations of the cause of epidemics. He jokingly referred to their Baconian "idola", in other words, their shibboleths.

${ }_{75}$ Laycock wrote "How one dies after the other at almost regular intervals and equal to those between our births! Every two years, more or less, one was born and every two years one dies" (J, 206). For his papers on proleptics see "Evidence and arguments in proof of the existence of a general law of periodicity in the phenomena of life', Lancet, $1842-3$, i: $124-8,160-4,423-7,929-33$; ii: $438-44,826-30$; $1843-4$, i: $85-9$, 253-8, 430-32; 1844, i: 523-4. They outline the theoretical underpinnings of his public health work on the nature and recurrence of fevers and epidemics. Laycock believed understanding the general periodicity of Nature held the key to the prediction of disease and hence its prevention. In practical terms, he advocated the keeping of mortuary records and the pursuit of medical meteorology as instruments of prediction. He argued that the latter had a particularly important bearing upon the laws of political economy and therefore affected population and society as a whole.

76 'Odyle, mesmerism, electro-biology', Br. for. med. chir. Rev., 1851, 8: 378-431; 'Modern demonology and divination', J. psych. Med. ment. Path., 1854, 7: 1-23.
} 


\section{Introduction}

in part due to his failure to find "a suitable help-mate" (J, 234). The disappointments of early loves, including the surgeon's daughter Mary Spence (J, 13, 72-4, 81-6); his unfruitful liaisons with young women at London chapels (J, 105-8); and his treatment at the hands of the gentrified Albina Dalton (J, 229-32, 235) all had their effect. ${ }^{77}$ His sense of women's inferiority also derived as much from the Bible as any medical appreciation of their so-called "special physiology". ${ }^{78}$ Finally, his published clinical lectures at the York Medical School and his reviews in the mid-1840s are full of allusions to his various activities as a local practitioner, especially the opposition he encountered on sanitary reform in relation to the health of towns question. ${ }^{79}$

As one might also expect, many of his views on medical reform bore the marks of his own professional experience as a York GP. He was an advocate of "one faculty", a position which implied not only the reform of the heterogeneous corporations which licensed practitioners, but also rejection of the tripartism of physician, surgeon and apothecary. ${ }^{80}$ In place of these traditional axes which had defined the medical profession for centuries, he proposed a new classification in terms of three functions which medical men performed in relation to the State. These he termed civic, military and political medicine. The latter comprised "the prevention of disease as well as the application of medical science to the moral advancement of mankind", and was subdivided into forensic, hygienic, eleemosynary, and colonial medicine, and medical education. ${ }^{81}$ Laycock's 'Letters on

${ }^{77}$ Laycock's "poverty and low birth" let him down in the eyes of the Daltons but, six years later, he eventually married Anne Lockwood (1848). He described theirs as "a happy union" to which he had been guided by "Divine Providence" (J, 236). See his correspondence with his "help-mate" in the 'Account': A, 61, n 8; 68, n 26, 27; 69, n 28, 29; 72, n 32, 34; 78, n 46; 82, n 57; 87, n 69, 70; 97, n 88, 90, 91.

78 Among Laycock's favourite books of the Bible, Proverbs, Solomon, and Daniel all emphasise the inferior place of women. See also the section 'Manhood and womanhood' in Mind and brain, 2nd ed., vol. 2, pp. 481-4. Laycock was an active opponent of the medical education of women in Edinburgh. For his attitude to the prospect of women attending clinical lectures at the Royal Infirmary, see his letter to Peter Bell, 2 November 1872, LHSC MS LHB1/73/9. This is reproduced along with others by Infirmary staff at the time in Michael Barfoot, "To do violence to the best feelings of their nature:" the controversy over the clinical teaching of women medical students at the Royal Infirmary of Edinburgh, 1869-74, Edinburgh, Medical Archive Centre, 1992.

${ }^{79} \mathrm{See}$ 'A clinical lecture on summer diarrhoea, cholera, and typhus fever, delivered at the York Medical School', Lond. med. Gaz., 1846, 3: 227-35, on p. 233: "a proprietor of cottage property in this city applied lately to the magistrates against his assessments to the poor's rate, on the ground that, since I had reported the locality of his houses to be unhealthy, his rental had diminished;" 'A clinical lecture on scrofula ..., ibid., 911-15, on p. 914: "you have first to enter a damp narrow passage from the street, then you ascend a narrow staircase, slippery with dirt, and nauseating from the heavy foetid atmosphere within it ...".

${ }^{80}$ Waddington, op. cit., note 7 above, pp. 165-7, identifies Laycock's views as the clearest expression of the "radical position" on medical reform. For an opposing view, see Robert Christison, "Organisation of Medical Profession in Scotland' and his covering letter to the Lord Advocate, 1 May 1849, Records of the Lord Advocate's Department, in SRO MS AD58/155. If, as seems likely, Laycock identified with moderate Peelite Conservatives, this in no way stopped him co-operating with the utilitarian Chadwick, or the radical Thomas Wakley, whose Lancet also took a "one faculty" position on medical reform.

81 'Letters on political medicine', Dubl. med. Press, 1841, 5: 167-8, 202-3, 235-7, 265-7, 315-16, 369-70, $420-1$; ibid., 1842, 6: $43-4$, on p. 168. In view of Laycock's two election contests, perhaps the most ironic remarks are about Resident Medical Officers in hospitals, ibid., p. 369: "It is notorious that there is almost invariably a struggle for each vacancy, and that merit has not the slightest chance of success against wealth, family connexions, low intrigue, or underselling. Those with whom the patronage rests are incapable of deciding the merits of the rival candidates. All produce an abundance of testimonials, and all make a shew of being equally qualified to fill the office, so further inquiry is considered unnecessary; and private bias, or more frequently, bribes-bribes to individuals, or bribes to the main body of subscribers to the charity, in the shape of donations, decide the election. It cannot be [a] matter of surprise, if the most incompetent candidate be frequently the most successful". 


\section{Michael Barfoot}

political medicine' show he believed the medical profession should play a more systematic and important role than it had done previously. He used this opportunity to outline the public side of his medical Fichteanism. Medicine, he prophesied, was destined to shape the physical and moral well-being of the nation and spread Christian knowledge throughout the Empire. He reiterated his view that "a truly philosophic physician is Godlike", and he envisioned a body of similarly minded medical men in the service of the State. $^{82}$

When writing anonymously, Laycock took whatever opportunities were offered to spread the word and "puff" his own writings. For example, he discussed his Lancet papers on "proleptics" in the British and Foreign. ${ }^{83}$ When the first report of the Health of Towns Commission was published, he drew plenty of attention to his own statement of conditions in York. ${ }^{84}$ When reviewing works on the nervous system, his own description of the reflex function of the brain always figured prominently. ${ }^{85}$ In the 'Account' he was critical of Daniel Noble, an acquaintance and fellow-practitioner from Manchester, because Noble always craved friends to write approving reviews of his work (A, 56). Laycock never had to ask for such favours because he managed it quite effectively by himself. ${ }^{86}$ When he submitted his Catalogue to the patrons of the University, there were over 150 entries on it (EC, 5-24). The contents represented a professional and personal march past which began with brief ant-like entrées on topics such as the use of water cushions, and culminated in elaborate and busy articles on brain function. By means of his writings, especially the essay reviews, Laycock claimed to have influenced the profession on topics such as hysteria, cerebral physiology, hygiene, medical ethics and reform, and several other aspects of mental disease. The list also showed the extent of his contributions to clinical medicine, with papers on fevers, skin and chest diseases, alcoholism, gout, dropsy and other subjects.

Publishing the Catalogue was tantamount to acknowledging authorship of many papers for the first time. Going public in this fashion ran the risk of exposing him as a partisan of his own work and of making new enemies because of outspoken statements made in reviews. The persistent reader could easily have traced the ways Laycock puffed himself. However, the assumption behind the Catalogue was that the articles themselves would never be read by those most concerned in his election. To minimise the possibility of new antagonisms, Laycock was prepared to sacrifice some publications and he kept quiet about reviews of works by Samuel Dickson and Marshall Hall, for example. ${ }^{87} \mathrm{He}$ also suppressed an interesting review of Carpenter's work on teetotalism in which Laycock took the pledge to consume in moderation, a position which some councillors and a

${ }^{82}$ Ibid., 167, quoting Hippocrates. See also, op. cit., note 63 above, p. 22.

83 'On periodic vital phenomena', Br. for. med. Rev., 1844, 18: 165-79.

${ }^{84}$ Op. cit., note 74 above, especially, pp. 494-5, 503.

85 'Body and mind', Edin. Rev., 1856, 103: 423-52, on pp. 434-5. Laycock also supported his position by translating the works of $\mathrm{J}$. Unzer and G. Prochaska and interpreting their ideas about reflex function in accordance with his own.

${ }^{86}$ But see 'Mr Noble on the brain and its physiology', Br. for. med. Rev., 1846, 22: 488-544. Internal evidence suggests this is by Laycock, but he omitted it from his Catalogue, probably to avoid offending one of his supporters.

${ }^{7}$ 'Dr. Marshall Hall's “Observations in Medicine”, Br. for. med. Rev., 1847, 23: 185-216; 'Dickson's "Fallacies of the Faculty", ibid., 1843, 15: 124-31. 


\section{Introduction}

significant portion of the wider Edinburgh public would have found hard to swallow. ${ }^{88}$ Finally, he took care not to publicise the various controversies he had engaged in under his own name by means of letters to the Lancet and elsewhere. For all this self-imposed censorship, there was plenty left which he could and did acknowledge. Some of his publications were slight but, taken together, they reflect an enormous appetite for medical publishing which few other busy practitioners could have equalled. At the same time, the presentation of the Catalogue was a carefully stage-managed affair to make the most of what he had done. It was planned right down to the sizes of typefaces used in different sections. It was one turn in a skein of strategies reeled off during the campaign for Alison's chair.

\section{"In war everything must be turned to account" $(\mathrm{A}, 59)$}

The Scotsman of 3 October 1855 contained two stories of considerable interest to its local Edinburgh readership. One was as follows:

EXPLOIT OF A HIGHLAND DRUMMER

The other morning when the Russians bolted from the Redan, Robert MacReady (of Edinburgh) "the big drummer" of the 42d, chased three Russian bandsmen, captured and drank their raki, and also brought off their biggest drum as a prize, which is at this moment the regimental drum of the royal $42 \mathrm{~d}$, and played by himself. ${ }^{89}$

The other appeared under the heading of "Town Council Proceedings" and soberly recorded the final outcome of another campaign by which Laycock, the little drummer, succeeded in capturing the most prized position of the Edinburgh Medical School (A, 97, n 92). Some of the atmosphere generated by the Crimean War infused the rhetoric and perhaps even the conduct of the election. The language of "campaign", "policy", "battle" and "victory" was routinely employed to describe nineteenth-century political life, but the international situation gave it a new sense of urgency and ensured it would be used with greater self-awareness by Laycock and others involved.

The repercussions of Laycock's success were slow to sink in at first, not least among the disappointed candidates. Only William Tennant Gairdner, the co-favourite of the ExtraAcademical School, a man supported by the "old Whig" party in Edinburgh, and with strong family connections in the Edinburgh Royal College of Surgeons, would live to fight another day (A, 69-70). He eventually became Professor of Medicine at Glasgow in 1862. Alexander Wood, another extra-academical lecturer, was Secretary to the Royal College of Physicians and popular there among those not allied to the professorial fellows or University party $(A, 69)$. This and the apparent support of the Free Church element on the Town Council made him so confident of victory that he had ordered a champagne lunchonly to find that it was Laycock who drank in all the success (A, 96). John Hughes Bennett, Professor of the Institutes of Medicine, was strongly supported by an influential group of professors within the Medical Faculty and had prominent Church of Scotland

\footnotetext{
88 'On the use and abuse of alcoholic liquors', Br. for. med. chir. Rev., 1851, 7: 46-83. For the attribution, see Laycock Collection, RCPE MS box 21, file 142.

${ }^{89}$ Scotsman, 3 October 1855.
} 


\section{Michael Barfoot}

connections (A, 69; 107, n 124). Much to everyone's surprise, he was eliminated at the first vote. Consumed by an overwhelming sense of the injustice of Town Council University patronage, he was already planning his revenge on councillors and the professor-elect alike $(\mathrm{A}, 100)$.

\section{"The patrons as they delight to be styled"}

Prior to the Universities (Scotland) Act, the government of Edinburgh University was formally vested in the municipal government of the city. ${ }^{91}$ In effect, the "Tounis College", as it was originally known, was a professional corporation within a municipal corporation. The principal and professors of the Senatus Academicus were ultimately accountable to the authority of the Lord Provost, magistrates and councillors who together composed the Edinburgh Town Council. ${ }^{92}$ The patronage of most chairs, including the majority of the medical ones, resided with them, the main exceptions being regius or crown appointments. ${ }^{93}$ Until the Burgh Reform Act of 1833, Edinburgh Town Council was closely managed politically by "the people above". 94 In the absence of a Secretary of State for Scotland between 1727 and 1886, men such as Archibald third Duke of Argyll, Robert Dundas and his nephew Henry, first Viscount Melville, the "uncrowned King of Scotland", presided over "the gravy train" of appointments. ${ }^{95}$ From collectors of the cess to the election of medical professors; from the preferment of parish ministers to the selection of commissioners of customs; from the councillors carefully picked from long and short "leets" submitted by the incorporated trades, to the recommendation of judges, lord advocates, barons of exchequer, and Edinburgh's MP, every Edinburgh "place" was filled in consultation with the ruling political interest of the day. There was a clear chain of communication and decision-making. At its greatest extent this stretched from the King to

90 James Syme, Letter to Editor, in The Times, 16 July 1858.

91 On institutional history of the University see, Sir Alexander Grant, The story of the University of Edinburgh during its first three hundred years, 2 vols, London, Longmans, Green, 1884; D. B. Horn, A short history of the University of Edinburgh, Edinburgh University Press, 1967. On its wider role in the nineteenth century, see Laurance James Saunders, Scottish democracy 1815-1840: the social and intellectual background, Edinburgh, Oliver and Boyd, 1950, pp. 307-70; George Elder Davie, The democratic intellect: Scotland and her universities in the nineteenth century, Edinburgh University Press, 1961; R. D. Anderson, Education and opportunity in Victorian Scotland: schools and universities, Oxford, Clarendon Press, 1983.

${ }^{2}$ On the eighteenth-century Town Council see, Jeremy J. Cater, 'The making of Principal Robertson: politics and the University of Edinburgh in the second half of the Eighteenth Century', Scot. hist. Rev., 1970, 49: 60-84; Alexander Murdoch, 'The importance of being Edinburgh: management and opposition in Edinburgh politics, 1746-1784', ibid., 1983, 62: 1-16. The Council also held the patronage of Edinburgh's established churches, appointing ministers in the manner of parish heritors elsewhere. See Richard B. Sher, 'Moderates, managers, and popular politics in mid-eighteenth-century Edinburgh: the Drysdale "Bustle" of the 1760s', in John Dwyer, Roger A. Mason and Alexander Murdoch (eds), New perspectives on the politics and culture of early modern Scotland, Edinburgh, John Donald, 1982, pp. 179-209.

93 Additional information on the histories of the various chairs is contained in David Bayne Horn, Papers on Modern History, and on the History of Edinburgh University, in EUL MS Gen 1824, boxes I and II.

94 Alexander Murdoch, "The people above": politics and administration in mid-eighteenth-century Scotland, Edinburgh, John Donald, 1980. See also John Stewart Shaw, The management of Scottish society 1707-1764: power, nobles, lawyers, Edinburgh agents and English influences, Edinburgh, John Donald, 1983; Ronald M. Sunter, Patronage and politics in Scotland, 1707-1832, Edinburgh, John Donald, 1986.

95 John Simpson, 'Who steered the gravy train, 1707-66', in N. T. Phillipson and Rosalind Mitchison (eds), Scotland in the age of improvement: essays in Scottish history in the eighteenth century, Edinburgh University Press, 1970, pp. 47-62. 


\section{Introduction}

the Prime Minister, to the Home Office, and to the likes of Argyll and the Dundases. From there, it went to the Lord Advocate and other highly placed members of the Scottish legal establishment; and then to the various local agents including MPs, lord provosts, councillors, university principals, and on downwards. Representations on behalf of place seekers were continually passing upwards in the opposite direction within the same system. The precise channels of consultation varied with the appointment but the overall structure remained largely unchanged throughout the century. ${ }^{96}$

During the expansion of the Edinburgh Medical School from around 1750 onwards, it is generally accepted that the Town Council's patronage of the University was skilfully handled. ${ }^{97}$ Keen private contests sometimes led to public repudiations of the manner in which the Council dispensed patronage, but it was always relative to particular instances rather than an attack on the principle of municipal patronage itself. ${ }^{98}$ The form of criticism based upon individual instances intensified during the late eighteenth and early nineteenth centuries when medical appointments tended to go to the sons of Edinburgh professors. ${ }^{99}$ The Tory bias of the Council was very apparent to local Edinburgh Whigs and this ensured a great deal of booing and hissing and over appointments where it was considered that a "better man" had been passed-over for overtly political reasons. ${ }^{100}$ Even so, it must be reiterated that no one yet advocated actually taking the patronage away. The predominance of jobbery in university appointments by successive Whig as well as Tory governments guaranteed an element of routine in all the apparently earnest protests and stern defences which were cranked out. After all, patronage was an accepted fact of public life.

On the occasions when new regius chairs were created, it was resented by professors and councillors alike, albeit for different reasons. The Town Council saw crown appointments as outside threats to their overall patronage of the University. The professors opposed the additions to the curriculum which new chairs implied, especially when it infringed an existing professor's monopoly over the teaching of a particular subject. Even

\footnotetext{
96 The best sense of how such arrangements affected Scottish scientific and medical culture comes from the published and unpublished work of Roger L. Emerson. Most recently, see his Professors, patronage and politics: the Aberdeen universities in the eighteenth century, Aberdeen University Press, 1992, pp. 1-9, and 'Medical men, politicians and the medical schools at Glasgow and Edinburgh 1685-1803', in A. Doig, et al. (eds), William Cullen and the eighteenth-century medical world, Edinburgh University Press, 1993, pp. 186-215.

97 J. B. Morrell, 'The Edinburgh Town Council and its University, 1717-1766', in R. G. W. Anderson and A. D. C. Simpson (eds), The early years of the Edinburgh medical school, Edinburgh, Royal Scottish Museum, 1976, pp. 46-65. There is some doubt, however, about how much judgement Council members could exercise in the choice of candidates. See, for example, Lord Provost George Drummond to William Cullen, 3 February 1756, in John Thomson (ed.), An account of the life, lectures and writings of William Cullen, M.D., 2 vols, Edinburgh, William Blackwood, 1859, vol. 1 (originally published in 1832), pp. 94-6. The limited scope for personal initiative which Argyll and others allowed Drummond is also referred to in Thomas Sommerville, $M y$ own life and times 1741-1814, Edinburgh, Edmonston and Douglas, 1861, p. 380.

${ }^{9}$ See, for example, the events surrounding the contest for the Practice of Physic Chair in 1766, in Thomson, op. cit., note 97 above, vol. 1, pp. 144-61.

${ }_{99}$ Horn, op. cit., note 91 above, p. 108, states that between 1786 and 1807, eight out of ten appointees were the sons of professors, although not all of them were medical professors' sons.

${ }^{100}$ For a Whig view of the Tory Council during this period, see Henry Cockburn, Memorials of his time, Karl F. C. Miller (ed.), University of Chicago Press, 1974, pp. 87-91. On how the Medical School fared, see Christopher Lawrence, 'The Edinburgh medical school and the end of the "old thing", 1790-1830', Hist. Univs., 1988, 7: 259-86, especially on p. 273, which discusses why the Whig John Thomson failed to be elected Professor of the Practice of Physic in 1821.
} 


\section{Michael Barfoot}

when there was no direct threat of internal competition, objections were still raised. Given the same or similar numbers of students, more professors meant a thinner slice of the class fee cake, that academic aliment which so many professors depended upon for their subsistence. ${ }^{101}$

While the foundation of new regius chairs could produce unholy alliances between professors and councillors, such co-operation was comparatively rare. ${ }^{102}$ The municipal constitution of the University was an enduring source of ill-feeling between them. Conflict intensified in the mid-1820s, when the Town Council recommissioned James Hamilton Junior, the incumbent Professor of Midwifery, making him Professor of Medicine, Midwifery and the Diseases of Children. ${ }^{103}$ This change of title was highly significant and implied new and important rights. Just as the University can be thought of as a corporation within a corporation, prior to 1833 there was also a "medical faculty" within the Medical Faculty. It consisted of an inner group of professors who had the word "medicine" (or "physic") written into their commissions of office. This brought with it special privileges. ${ }^{104}$ It entitled the subjects they taught to be compulsory for students taking degrees. Only they could examine and receive graduation fees. They alone among the professors were able to teach using the University's clinical wards in the Royal Infirmary, should they wish to do so. ${ }^{105}$

By changing the midwifery commission in this way, the Town Council was prescribing the curriculum retrospectively for would-be graduates who had already commenced their studies. It was this aspect in particular which gave great offence. Throughout the ensuing dispute, the College Committee of the Town Council continued in its time-honoured role of go-between, with a steady stream of protests passing from the Senatus and a relay of

101 On the class fee system and its implications for teaching, see J. B. Morrell, 'The University of Edinburgh in the late eighteenth century: its scientific eminence and academic structure', Isis, 1971, 62: 158-71. The University reeled from one financial crisis to another during the first half of the nineteenth century, which is only to be expected from an institution which paid its professors out of a locally collected ale tax.

102 See the draft letters of G. Lamb to Lord Provost, 12 December 1831, referring to a joint memorial between the Senatus and Town Council opposing the regius chairs of Medicine and General Pathology and Medicine and Surgery, Records of the Lord Advocate's Department, in SRO MS AD58/178. The University and the Town Council also co-operated in opposing the chartership of University College. See Town Council Minutes, 14 January 1836, ECA MS SL7/1/220 (15 October 1835-16 February 1836), p. 322.

${ }^{103}$ For summary of events, see Grant, op. cit., note 91 above, vol. 2, pp. 17-36; For Hamilton's version, see Evidence, oral and documentary, taken and received by the commissioners . . for visiting the universities of Scotland, 4 vols, London, W. Clowes for H.M.S.O, 1837 (in Parliamentary papers, vol. 35), vol. 1, 'Edinburgh evidence', p. 315.

104 The origins of these distinctions between medical professors and the relationship between the Medical Faculty and Senatus are difficult to document because of the lack of early records. But for the foundation of the Faculty and the voting rights of its members, see Papers Illustrative of the History and Constitution of Edinburgh University, 2 vols, EUL MS Dc 1.4, vol. 1, fol. 92, Until Hamilton's commission was altered in 1824, only six professors were members of this "medical faculty" within the Medical Faculty (Practice of Medicine, Institutes [Theory] of Medicine, Medicine and Chemistry, Medicine and Botany [from 1738], Medicine, Anatomy and Surgery [from 1754], and Medicine and Materia Medica [from 1768]). Regius professors such as those of Natural History (1770), Clinical Surgery (1803), Military Surgery (1806) and Medical Jurisprudence (1807) were relegated to the Medical Faculty in the larger sense. However regius chairs of Medicine and Pathology, and Medicine and Surgery were created in 1831, and Medicine and Chemistry reverted solely to Chemistry in 1844.

${ }^{105}$ For the origins of these arrangements, see Royal Infirmary of Edinburgh, Managers' Minutes, January 1742-January 1749, LHSC MS LHB 1/1/2, pp. 169-70. See also, The professors of clinical medicine [Christison, Alison and Bennett], Observations on the system of clinical instruction in the Royal Infirmary of Edinburgh, Edinburgh, Neill, 1848. 


\section{Introduction}

orders marching from the City Chambers. Both bodies rarely came face to face; the exception being an official "Visitation" on 10 November 1825. The Senatus mounted a legal challenge against what they interpreted as an unwarranted curricular fiat, deviously imposed by socially inferior municipal men upon their professional betters. However, the claim of the Senatus to govern the content of the medical curriculum by legal rather than moral right was eventually thrown out by the learned Lords of Session in 1829.

Even if the legal decision had been in their favour, members of the University and their supporters who were hostile to Town Council control knew it would take more than a pending decision of the Court of Session to advance the cause of institutional reform. Therefore they also succeeded in persuading the Tory government and its Home Secretary, Robert Peel, that a Royal Commission was needed to review the Scottish university system as a whole. ${ }^{106}$ It began taking its Edinburgh evidence while the University's lawsuit was still proceeding through the courts. Notwithstanding the ruling against the principal and professors, the commissioners' General report (1831) was highly critical of the way the Council had managed the University's internal affairs. ${ }^{107}$ As well as recommending specific changes to the medical curriculum, it also favoured reorganisation of Edinburgh and other Scottish universities to bring them more into line with the model of government found in England. However, with respect to Edinburgh where the proposed reforms would be the most far-reaching, the commissioners also made it clear that

we by no means contemplate any interference with the rights of patronage of the Magistrates and Council of the City in regard to the appointment of the Principal and Professors, as hitherto enjoyed and exercised by them. We are of opinion that these rights should remain untouched; . . ${ }^{108}$

Nor did the new Whig government which inherited the Commission's recommendations do anything to advance the cause of university reform by taking away the patrons' rights. It merely side-stepped the issue by creating two further regius medical chairs, one of which was for a long-suffering supporter, John Thomson, who came out of the political wilderness to be appointed Professor of Medicine and General Pathology. ${ }^{109}$

Professors of most subjects in the wider Medical Faculty were not placed on a more equal footing until three month courses in natural history, medical jurisprudence and clinical surgery were also made compulsory for graduation as a result of new regulations issued by the Senatus and approved by the outgoing unreformed Town Council in $1833 .{ }^{110}$

\footnotetext{
106 For background to the Commission, see Grant, op. cit., note 91 above, vol. 2, pp. 36-53; Saunders, op. cit. note 91 above, pp. 317-19; J. B. Morrell, 'Science and Scottish university reform in 1826', Br. J. Hist. Sci., 1972, 6: 39-56, on pp. 40-2; Lisa Rosner, Medical education in the age of improvement: Edinburgh students and apprentices 1760-1826, Edinburgh University Press, 1991, pp. 175-94.

${ }^{107}$ Report of the Royal Commission into the state of the universities of Scotland, London, William Clowes for HMSO, 1831 (in Parliamentary papers, vol. 12), p. 18 and passim.

108 Ibid., p. 11.

109 For details of the ensuing controversy, see L. S. Jacyna, Philosophic whigs: medicine, science, and citizenship in Edinburgh, 1789-1848, London, Routledge, 1994, pp. 105-12. The Government eventually agreed that the patronage would revert to the Town Council on Thomson's resignation.

${ }^{110}$ In 1825, the original "Statuta Solennia" of 1767 were modified by the Senatus to take some account of these subjects, but the Senate's right to frame new regulations was disputed by the Town Council. In the final agreed version of 1833 , military surgery disappeared as a degree requirement, while a course of practical anatomy was made compulsory.
} 


\section{Michael Barfoot}

This virtually eliminated the significance of the divide between the two medical faculties, with the exception that clinical teaching at the Infirmary was still restricted to professors of medicine only. ${ }^{111}$ The wider distinction between the University and Extra-Academical School was eroded further when, in 1843, the Town Council allowed certain extramural classes to count towards graduation. ${ }^{112}$ Understandably, the Medical Faculty opposed this move and they received the complete support of the Senatus. The subsequent legal battle lasted until 1855 but, once again, it was won by the Town Council. ${ }^{113}$ As a result, the legal power to govern the University remained firmly with them throughout the first half of the nineteenth century. They retained rights of patronage over the majority of the University's chairs and never enjoyed it more than when candidates for medical professorships requested their suffrages, as they did in the close run contest for the Practice of Physic in 1855.

Soon after the university commissioners reported, the Burgh Reform (Scotland) Act of 1833 established a system for the direct election of town councillors by a group of recently enfranchised voters. ${ }^{114}$ Thirty-one ward based councillors replaced the former oligarchic dominance of the merchant guilds and incorporated trades. ${ }^{115}$ To some it seemed that the older form of politics had vanished overnight. ${ }^{116}$ However limited the ten pounds franchise actually was, it led to an irrevocable breakdown of the former method of political control by "the people above". One specific manifestation of this was the greater autonomy enjoyed by councillors over the choice of professors. Prior to 1833, the Town Council's patronage was government guided. Afterwards the municipal men had a more or

${ }^{11}$ Early in June 1829 the Managers of the Royal Infirmary agreed in principle that their ordinary physicians should be allowed to give clinical lectures. The plan put forward was finally accepted on 10 October 1831. See Royal Infirmary of Edinburgh Managers' Minutes, September 1824-October 1831, LHSC MS LHB1/1/10, pp. 318-19, 436-7. This marked the formal beginning of extra-academical medical clinical teaching in the Infirmary.

${ }^{112}$ See Town Council Minutes, 12 April 1842, ECA MS SL7/1/236 (26 November 1841-26 April 1842), pp. 422-3. The 'Report of the College Committee on the propriety of altering the regulations which require attendance at University-classes exclusively, as qualifying candidates for the degree of M.D.' was presented at this meeting. After further discussion and delays, on 20 September 1842, it was finally agreed to adopt new regulations to this effect, commencing in the 1843-4 session. See ibid., SL7/1/237 (3 April 1842-11 October 1842), pp. 354-7.

113 See Douglas Guthrie, Extramural medical education in Edinburgh and the school of medicine of the Royal colleges, Edinburgh, E. and S. Livingstone, 1965, p. 43; John D. Comrie, History of Scottish medicine, 2nd ed., 2 vols, London, Baillière, Tindall and Cox for Wellcome Historical Medical Museum, 1932, vol. 2, pp. 585-6; Sophia Jex-Blake, Medical women: $a$ thesis and a history, 2nd ed., Edinburgh, Oliphant, Anderson and Ferrier, 1886 , pp. $163-4$.

114 On the general background to the 1832 reforms which preceded this Act, see W. Ferguson 'The Reform Act (Scotland) of 1832: intention and effect', Scot. hist. Rev., 1966, 45: 105-14; Michael Fry, Patronage and principle: a political history of modern Scotland, Aberdeen University Press, 1987, pp. 27-58; Michael Lynch, Scotland: a new history, London, Century, 1991, pp. 397-421, especially on pp. 414-17; I. G. C. Hutchison, $A$ political history of Scotland 1832-1924: parties, elections and issues, Edinburgh, John Donald, 1986, pp. 1-102.

115 D. Robertson, et al., Edinburgh 1329-1929, Edinburgh, Oliver and Boyd, 1929, pp. 312-13; John Charles Williams, 'Edinburgh Politics 1832-1852', PhD thesis, University of Edinburgh, 1972, pp. 49-54.

${ }^{116}$ Henry Cockburn, Journal . . . being a continuation of the "Memorials of his time" 1831-1854, 2 vols, Edinburgh, Edmonston and Douglas, 1874, vol. 1, pp. 51, 53-4; Williams, op. cit. note 115 above, p. 54. The new structure of thirty-one councillors, a Dean of Guild and a Convener of Trades was still in place at time of Laycock's election but, in 1856, membership had increased to 41 because of extensions to the Burgh. 


\section{Introduction}

less free hand when dispensing their academic patronage, with the Lord Advocate confining his attention to regius chairs or those in which the patronage was shared. ${ }^{117}$

The majority of the new councillors were ordinary Edinburgh traders of the middling mercantile orders. The perceived change in the social and occupational composition of the Town Council towards the "shopocracy" had a gradual but profound effect on wider public opinion about its fitness to dispense academic patronage. ${ }^{118}$ With regard to preReform patronage, it was doubted whether a councillor was ever really free to choose between professorial candidates, even when he was a well-educated merchant, an accepted member of "polite" local society and intellectually able to make the necessary judgements. When the new style councillor qua tradesman acquired greater autonomy of decision making, criticism shifted its ground. Opponents now doubted whether he was intellectually fit to exercise that freedom of choice, especially in view of religious and political attitudes he increasingly shared with "the people below" who had elected him. ${ }^{119}$

1833 also saw a Commission on the Municipal Corporations of Scotland pass under the Great Seal. It provided a further opportunity for the patronage question to be reconsidered in a manner which took account of the changes in the mode of election and composition of the reformed Edinburgh Town Council. ${ }^{120}$ Its General report (1835) reveals there was complete agreement that the internal government of the University was woefully inadequate; and the Town Council's most recent impositions upon the medical curriculum were again condemned as highly undesirable. A majority of commissioners were actually in favour of the patronage being taken away. ${ }^{121}$ Once again, though, no changes occurred, much to the chagrin of many within the University community. ${ }^{122}$ Nor did the comprehensive volume from the Universities Commission, which eventually appeared in 1837, restart the stalled engine of legislation. Rights of patronage sanctioned by law and maintained by custom were rarely interfered with by governments of either persuasion unless there were compelling reasons to do so. Crown patronage epitomised this, but the principle could readily be extended to municipal corporations. Even the privileges of the different medical corporations were not easily adjusted, as many would-be medical

\footnotetext{
${ }^{117}$ In similar fashion, the Council's church patronage now came under direct control. Williams, op. cit., note 115 , p. 133, argues that successive governments' failure to deal with religious faction in the city after Reform, contributed greatly to their general loss of influence over all the Town Council's decisions.

118 There is some doubt about how the social composition of the new Town Council differed from the old. See Cockburn, op. cit., note 116 above, vol. 1, p. 54, who stated that "persons higher in station and in wealth" had been chosen after 1832, but his comments seem to be about Scotland as a whole rather than Edinburgh. Williams, op. cit., note 115 above, pp. 401-2, confirms the extent of mercantile and retailing representation on the new Council, but he argues that the social composition of the new Council did not change dramatically (on p. 50). However, it must remain doubtful whether the social standing of councillors can ever be assessed by occupation alone.

${ }^{119}$ Syme's letter to The Times of 16 July 1858 is only one example of a whole ground-swell of hostile opinion about the new Council's fitness in this respect.

${ }^{120}$ General report of the commissioners appointed to inquire into the state of municipal corporations in Scotland, London, William Clowes for HMSO, 1835, (in Parliamentary papers, vol. 29). It passed under the Great Seal on 15 July 1833, just before the Burgh Reform Act was passed. However, the evidence was taken afterwards, between October 1833 and September 1834. Witnesses therefore had a unique opportunity to look back upon how patronage was handled by the unreformed Council and forward to how the University might fare under its successor.

121 Ibid., pp. 69-74.

122 See Cockburn, op. cit., note 116 above, vol. 1, pp. 105-6.
} 


\section{Michael Barfoot}

reformers of the 1830 s and 1840 s learned to their cost. ${ }^{123}$ Because Scottish University reform was not a law and order matter, public and parliamentary opinion would have been very important in gaining support for any proposed legislation. Any views taken by Parliament would be shaped - although not exclusively so-by the recommendations of the commissions which had already considered the matter. Here lay an immediate difficulty. While critical in almost every other respect, the Scottish Universities commissioners had sanctioned the Town Council's existing rights of patronage over University chairs. The commissioners on Municipal Corporations wanted them removed, but they were not unanimous. Apart from the problem of being seen to punish a Council which remained predominantly Whig after 1833 , the views of witnesses called before this Commission suggests that informed public opinion on the issue was genuinely divided to an extent that prospective legislation would have been difficult. ${ }^{124}$

The main effect of the published evidence originally heard before both Commissions was to promote a much wider public discussion about how appointments to professorships in Scottish universities should be made. During this process, Sir William Hamilton emerged as the authoritative commentator-in-chief by virtue of an influential article which originally appeared in the Edinburgh Review. ${ }^{125} \mathrm{He}$ was still Professor of Civil History at Edinburgh University at this time, having conspicuously failed to get the Chair of Moral Philosophy in a 1820 contest against John Wilson, the Tory's beloved "Christopher North". This and various other quarrels with the Town Council ensured their unusual and anomalous position as academic patrons would figure prominently in all Hamilton wrote. ${ }^{126} \mathrm{He}$ advocated an independent board patronage with a membership which reflected the interests of the various institutions involved in such decisions. ${ }^{127}$ However, when making this argument, he conceded (grudgingly) that, in an imperfect world, patronage by Town Council was preferable to the Crown and certainly better than letting the professors decide by themselves. ${ }^{128}$ In fact, Town Council patronage not only had its defenders throughout this period, some of them came from unexpected sources, including Edinburgh University medical professors. ${ }^{129}$

${ }^{123}$ Waddington, op. cit., note 7 above, pp. 77-95; Newman, op. cit., note 7 above, pp. 149-86.

124 A bill to regulate the Scottish universities was introduced in 1836-7 but it was defeated at an early stage.

125 [William Hamilton], 'Patronage of Universities', Edin. Rev., 1834, 61: 196-227. An amended version which took into account his evidence on curatorial boards given before the Royal Burghs Commission appeared as 'On the patronage and superintendence of universities', in idem, Discussions on philosophy and literature, education and university reform . . . , London, Longman and others, 1852, pp. 348-85.

${ }^{126}$ On the 1820 contest see, Fry, op. cit., note 114 above, p. 26. For Hamilton's subsequent disputes with the Town Council regarding the tenure of the Chair of Logic and Metaphysics, see Report by the College Committee of the Town Council, on the subject of the memorial to Lord Melbourne from the Senatus Academicus of the University of Edinburgh, Edinburgh, Thomas Allen, 1839, pp. 19-35; and John Veitch, Memoir of Sir William Hamilton, Bart., Edinburgh, William Blackwood, 1869, pp. 239-46.

${ }^{127}$ Hamilton originally proposed a board of six academic patrons nominated by the Faculty of Advocates, the Society of Writers to the Signet, the Royal Colleges of Physicians and Surgeons, the Presbytery of Edinburgh and the Town Council. The General report on the municipal corporations was in favour of five board members, two Town Council, two Crown and one Senatus nominee. Eventually four Town Council and three University Court representatives composed the Curators of Patronage under the arrangements of the 1858 Universities (Scotland) Act.

${ }_{128}$ Hamilton, op. cit., note 125 above, p. 218.

129 See General report, op. cit., note 120, pp. 361-4 (W. P. Alison); 375-6 (J. W. Turner); 376, 381-3 (T. C. Hope); 377-9 (J. Thomson). Among the medical professors who gave evidence, R. Graham (Medicine and Botany), Christison (Medicine and Materia Medica) and Syme (Clinical Surgery) were unambiguously against. 


\section{Introduction}

Even immediately before the 1858 Act, there were still well-known figures like Robert Chambers eager to defend the Council's record in public. Chambers was a self-made publisher, the secret author of Vestiges of the natural history of creation and a strong Laycock supporter behind the scenes. ${ }^{130}$ Because the Council had no scientific prejudices, no special favourites of its own to provide for, and was necessarily receptive to wider public opinion, Chambers argued it was eminently well suited to act as "trustees to the public":

It opens its eyes to testimonials, weighs testimonial-givers against each other, listens to the general opinion as to contending claims, and, having literally nothing to consider but what will be best for the community, it commonly justifies in the result, the approbation [of its supporters]. ${ }^{131}$

The opposite perspective was most graphically set out by James Syme, Professor of Clinical Surgery, writing in response to Chambers' letter. Having listed the councillors' occupations (which included upholsterer, grocer, spirit dealer, printer, ironmonger, jeweller, combmaker, hatter, plumber, currier, tea-merchant and cheesemonger!), he commented:

Every candidate for a chair in the University of Edinburgh, except those which are under the patronage of the Crown, must personally canvass all of these individuals and bring influence to bear upon each of them. He must publish volumes of testimonials, and have a committee constantly in action to promote his claims. It is needless to expatiate upon the trouble, expense, and moral degradation of such a process. The patrons, as they delight to be styled, from their position in society, have no means of knowing the merits of candidates, except through testimonials, as to the respective value of which they are no less incompetent to judge. They are in consequence exposed to private solicitation and the influence of sectarian prejudices, as may appear from the fact that at a late election, all of the Free Church members voted for one candidate, and all the Established Church members for another. ${ }^{132}$

Having purchased his regius chair from James Russell and been an influential member of Bennett's election committee in 1855 , Syme was nothing if not well informed. ${ }^{133}$

The events and circumstances which led to the Town Council losing de facto patronage over the University during the course of parliamentary debate on the Universities

\footnotetext{
${ }^{130}$ Robert Chambers to Editor, in The Times, 12 and 17 July 1858; [idem], Vestiges of the natural history of creation, London, John Churchill, 1844; James A. Secord, 'Behind the veil: Robert Chambers and Vestiges', in James R. Moore (ed.), History, humanity and evolution: essays for John C. Green, Cambridge University Press, 1989, pp. 165-94; M. Millhauser, Just before Darwin: Robert Chambers and "Vestiges", Middletown, Conn., Wesleyan University Press, 1959.

${ }^{131}$ Letter to Editor, in The Times, 12 July 1858. Once again, W. P. Alison, J.W. Turner, T. C. Hope and John Thomson were cited as supporters of Town Council patronage. In his second letter on 16 July, Chambers claimed that from 1843-58, there were twelve appointments by the Council and only three Free Churchmen among them.

132 The Times, 16 July 1858.

133 See letter relating to Syme's appointment, 13 November 1832, Records of the Scottish Home and Health Department, in SRO MS HH5/7. The deal between the Government, Syme and James Russell was satirised in the Lancet, 1832-3, ii: $157-60$.
} 


\section{Michael Barfoot}

(Scotland) Act has been well told by Horn. ${ }^{134}$ However, at the time of Laycock's election three years earlier, all of the legal and a significant amount of the moral power to govern the University remained firmly with them. Nor did they relish it more than when some of their staunchest critics among the medical profession came to ask for their suffrages. The Practice of Physic Chair was the last medical professorship to be contested under the old rules of engagement, and the scene was set for a memorable struggle. ${ }^{135}$

\section{"An Englishman and a stranger" (A, 61)}

A point the General report on municipal corporations drew attention to was that no foreigners (including English foreigners) who had not attended Edinburgh University had ever been appointed to a chair there. ${ }^{136}$ In 1836 , possibly in response to this criticism, the Council tightened up the procedure for electing professors. For a professorship to be offered without an open canvass, twenty councillors had to be in favour of the proposed candidate. When a canvass did take place, there had to be at least two months between the publicly announced vacancy and the appointment. ${ }^{137}$ The inevitable need to get new professors into harness before the teaching session began meant that the two months' rule was frequently set aside, however, and it was eventually abandoned as unworkable. ${ }^{138}$ Nevertheless, if it could possibly do so, the Council still sought to delay the period between announcement and appointment in order to enable prospective candidates outside Scotland to apply and be seen to apply. It also became increasingly necessary to allow time for the required batch of testimonials to be sought, printed and publicly digested beforehand.

Simpson's telegram to Laycock (A, 57, n 4) advising action rather than thought was apposite in this regard, even though the date of the election was still some seven weeks away. When he arrived in Edinburgh on 16 August, Laycock spent his first night at 52 Queen Street applying for testimonials $(A, 61) .{ }^{139}$ Eventually he presented nearly ninety

134 D. B. Horn, 'The Universities (Scotland) Act of 1858', Univ. Edinb. J., 1958-60, 19: 169-99, especially on pp. 184-6. The issue of a Court of Patronage was first raised as an amendment during the second reading. It had not figured in earlier drafts of Lord Advocate Inglis's Bill. Once he realised the mood of the House, however, he joined with those critical of the Town Council's exercise of patronage. After he became Chancellor of Edinburgh University, Inglis stated that on many occasions the Council's "administration of the patronage was so judicious as greatly to advance the reputation of the University by securing the services of the most distinguished and able men as professors". See Records of the tercentenary festival of the University of Edinburgh celebrated in 1884, Edinburgh, William Blackwood, 1884, p. 101.

${ }^{135}$ The last chair in the Medical Faculty to be contested was Chemistry which went to Lyon Playfair immediately before the Universities (Scotland) Act was passed. However, it was no longer a medical subject as such and Playfair was not medically trained. He was an unsuccessful candidate in 1844 (see note 104 above).

${ }^{136}$ The first was Philip Kelland who became Professor of Mathematics in 1838. See Davie, op. cit., note 91 above, pp. 118-23.

${ }_{137}$ Town Council Minutes, 29 March 1836, ECA MS SL7/1/221 (23 February-16 August 1836), pp. $109-10$. See also Alexander Morgan (ed.), University of Edinburgh: charters, statutes, and acts of the Town Council and the Senatus 1583-1858, Edinburgh, Oliver and Boyd, 1937, p. 191.

${ }_{138}$ Town Council Minutes, 3 March 1846, ECA MS SL7/1/245 (6 November 1845-12 May 1846), p. 305.

139 The practice of issuing testimonials in support of applications for medical chairs can be traced back to 1821 and may be older. Cockburn, op. cit., note 116 above, vol. 1, pp. 211-14, suggested it became the norm as political and sectarian opinion became more diverse. It was precisely this sort of social climate which encouraged widespread discussion not only about a man's testimonials, but also about the nature and role of testimony, evidence and belief in science and religion. See, for example, Robert Chambers, Testimony: its posture in the scientific world, Edinburgh, William and Robert Chambers, 1859. 


\section{Introduction}

printed letters of support, the majority of which were from known and highly respected medical men in all parts of Britain (T, 1-74). Other candidates were equally industrious. ${ }^{140}$ There was much contemporary criticism of the testimonial system. Some of the grounds for it are revealed in Laycock's own remarks and comments made in the surviving letters of testifiers, especially with regard to "finishing up", or re-writing references to better suit the occasion (A, 74, n 36). Simpson in particular was "arranging and concocting" testimonials with all the enthusiasm of a busy apothecary (A, 75). ${ }^{141}$ These behind-thescenes glimpses of how testimonials were crafted show they are much more interesting documents than is usually recognised. Testimonials functioned as social palimpsests in which hidden meanings counted for as much as overt contents. Letters which might appear in Laycock's favour could actually be damning in the eyes of an audience particularly adept in reading between the lines and appraising what had not been said. For example, Laycock had testimonials from several Edinburgh professors, including Alison and Christison, but he never printed one of them. Simpson's advice was that they were just not good enough $(\mathrm{A}, 62, \mathrm{n} 10)$. The standing of the testifiers was obviously very important and Laycock discussed those given (or not given) by the "medical baronets" in some detail (A, 62). However, the manner and style of less well known figures could be equally significant and Laycock placed great stress upon the expression of feeling by testifiers (A, 61). It would also have been routine for readers to compare testimonials given to more than one candidate and try to second-guess who the testifier "really" preferred. As some testimonials used on former occasions were often recycled, a candidate could already have inadvertently given one to a subsequent rival. This happened to Laycock and he had to explain a testimonial he had previously written for Alexander Wood (A, 73). Rather than cause others to frown on the smiling face of his host's professed neutrality, Laycock himself used a former testimonial by Simpson $(T, 11)$. This had been obtained in relation to the York County Hospital election of 1854.

There can be no doubt that Alison was a favourite and that councillors of all political and religious persuasions regretted his resignation through ill health. ${ }^{142}$ His private philanthropy in Edinburgh was much admired by men who always equated charity with religious duty. His championing of Scotland's poor on the sanitary question was widely respected. ${ }^{143}$ Public health, especially the health of towns, was never far from the concerns

\footnotetext{
${ }^{140}$ See William Tennant Gairdner, Chair of Practice of Physic in the University of Edinburgh . .., Edinburgh, (no publisher), 1855; Alexander Wood, Chair of Practice of Physic . . , Edinburgh, (no publisher), 1855; John Hughes Bennett, Chair of Practice of Physic . . . Edinburgh, (no publisher), 1855. See also, George Alexander Gibson, The life of Sir William Tennant Gairdner, Glasgow, James Maclehose, 1912, pp. 72-3; Thomas Brown, Alexander Wood: a sketch of his life and work, Edinburgh, Macniven \& Wallace, 1886, pp. 114-17; John G. M'Kendrick, John Hughes Bennett, Edinburgh, Oliver and Boyd, n.d., pp. 9-10.

${ }_{141}$ The full extent of this practice cannot be estimated because of the missing file of correspondence with testimonial-givers, but see the remarks in 'Account', A, 63, n 20.

142 See the report of Town Council proceedings in the Scotsman, 15 August 1855. However, in the private discussions between Alison, Principal Lee and Adam Morrison, Convener of the College Committee, Alison hinted at a possible separation between the formal lecturing requirements of the Chair and clinical duties at the Infirmary, and offered to continue with the latter only. This suggests that there may have been prior discussions between him and the other clinical professors, Bennett and Christison. See Alison to John Lee, 9 and 27 July 1855, and Alison to Adam Morrison (copy sent to Lee), 6 July 1855, in Lee Papers, NLS MS 3488, ff. 20, 23, 16.

${ }^{143}$ William Pulteney Alison, Observations on the management of the poor in Scotland, and its effects on the health of the great towns, Edinburgh, William Blackwood, 1840; idem, 'Illustrations of the practical operation of the Scottish system of management of the poor', J. Stat. Soc. Lond., 1840, 3: 211-57.
} 


\section{Michael Barfoot}

of the municipal government, although some time would still have to elapse before the first Medical Officer of Health for Edinburgh was appointed. ${ }^{144}$ During the week in which Alison's resignation was announced, the Scotsman carried articles about the report by the Cholera Committee on the 1854 epidemic; the imminent Scottish registration of births, marriages and deaths; and one on "smoke nuisance" by the Streets, Buildings and Sanitary and Drainage Committee of the Council itself. Laycock had expertise in all these areas and this was duly emphasised in his re-written First address (A, 60, n 7), then followed-up in the Testimonials (T, 29, 38-9, 42-3, 47-8, 65-6 etc.). ${ }^{145}$ The majority of his clinical experience had been gained in a "domestic" clinical practice centred on a dispensary, just as Alison's had at the New Town Dispensary before becoming a clinical professor at the Infirmary. ${ }^{146}$ Given the councillors' feelings of sympathy and respect for the epilepsystricken, pension-begging, lame-duck professor, Laycock's career-long commitment to caring for the poor would certainly have impressed them. ${ }^{147}$

Another concern which drew in councillors and citizens alike was the teaching ability of candidates. Edinburgh benefited materially as well as intellectually from a great teacher at the head of the University Medical School. More students meant increased prosperity for Edinburgh, not just for the "shopocratic" majority on the Council, but also the significant proportion of the town whose livelihoods were affected by the success of the University in their midst. Laycock's activities as a lecturer in the York School of Medicine was crucial in this regard. Testimonials from former pupils like Jonathan Hutchinson counted for much (T, 57; A, 63, n 20), as did the collective testimonials signed by students as yet undistinguished, such as John Hughlings Jackson $(\mathrm{T}, 58){ }^{148}$

In many ways, the most significant aspect of the teaching associated with the Practice of Physic Chair was the clinical component and not the formal lectures of the "systematic" class. This was because Edinburgh lacked a separate professorship of clinical medicine. As formerly noted, this duty could only be undertaken by those professors with that symbolic and powerful word "medicine" in their commissions. The bundling together of a very practical and demanding clinical component with the other responsibilities required an incumbent with very great energy and, increasingly, a man who was already an experienced practical physician. Laycock and the other candidates had to show-and keep showing - that they fitted the part and had already treated large numbers of patients successfully. Otherwise suspicions would arise as to their suitability for the post. Here

\footnotetext{
144 For background, see H. P. Tait, A doctor and two policemen: the history of the Edinburgh public health department 1862-1974, Edinburgh, Mackenzie and Storrie for EPHD, 1974; R. A. Cage, The Scottish Poor Law 1745-1845, Edinburgh, Scottish Academic Press, 1981.

145 Chadwick, John Simon, and Southwood Smith all gave Laycock good testimonials. He also circulated his publications on public health among the councillors (A, $72 \mathrm{n} 34$ ).

146 On the New Town Dispensary, see Statement regarding the New Town Dispensary, by the medical gentlemen, conducting that institution, Edinburgh, for the benefit of the charity, 1816.

${ }^{147}$ After his election, Laycock devoted a significant part of his practice of physic course to public health. See, for example, Laycock Collection, RCPE MS box 5, files 31-35. Later, he became a University examiner in the subject. However his direct involvement does not seem to have extended beyond caring for the sick poor in his Infirmary practice.

${ }^{148}$ Herbert Hutchinson, Jonathan Hutchinson: life and letters, London, Heinemann, 1946, pp. 30, 217; John Hughlings Jackson, Selected writings of John Hughlings Jackson, 1st ed., repr., 2 vols, New York, Basic Books, 1959, vol. 1, pp. 37, 47, 122-3, 167, 176, 179; vol. 2, pp. 6-8, 394, 483. He repeatedly emphasised Laycock was the font et origo of the reflex function of the brain, which Jackson then promptly re-baptised as "psycho-physical parallelism", launching the conceptual foundations of modern neuroscience as a result.
} 


\section{Introduction}

Laycock's humble beginnings in York County Hospital and his later work as Visiting Physician to York Dispensary stood him in good stead and showed he had the necessary hands-on experience gained in well known and respected institutions (A, 82, n 58). The need to be seen as a practical physician also affected the whole electoral presentation of his published work. The concern throughout was to emphasise the practical relevance of all his papers, even the most theoretically orientated ones (A, 72, n 33).

These and other points were quietly but emphatically delineated in his Catalogue, Testimonials and the four Addresses he published. All of them can be thought of in the same way as the candidate's calling card Laycock had specially printed in the first Edinburgh printing office he visited, which happened to be that of William Forrester, Town Councillor $(\mathrm{A}, 68)$. The Evidence stated who he was, what he had done and why he felt justified in asking for the suffrages of the patrons. Most of the hard work of begging testimonials, compiling the list of publications and adding favourable reviews of them was done during Laycock's first visit which lasted from 16-18 August. However, they were not yet published and, up to this point, the only contact he had with the councillors was through brief calls he made upon them, either to announce his intentions in person or to leave his card (A, 66, n 25). He did not return to Edinburgh until 10 September.

In the intervening period, Simpson continued to exert a Svengali-like influence, deciding the form of the Catalogue (A, 66), correcting Laycock's attempt to compose a First address (A, 61, n 9; 65, n 45) and advising on the presentation of testimonials. He did this either personally (A, 62, n 10), or through W. O. Priestley, Simpson's assistant (A, 74, n 37-40) or via William Carmichael, his "jackal" (A, 74, n 35). Before Laycock returned, he sent his recently printed First address, the first batch of Testimonials and the Catalogue to the all-important councillors. They were distributed by $\mathrm{Mr}$ William Finlay Watson, a well-known bookseller and print dealer at 52 Princes Street, especially recommended for the job because of his widespread local connections. ${ }^{149}$ After councillors, the next targets were members of the Edinburgh medical profession at large. Town councillors would naturally turn to their own GPs and medical friends for an opinion about a fellow professional. Laycock remarked that the effect of his printed Testimonials and Catalogue on the town was like a "bomb shell", but there was something of the delayed action device about them too. The Catalogue got him more testimonials; subsequent Addresses summarised general points that might otherwise be lost in individual testimonials; and the new letters of recommendation so obtained reflected and increased his reputation. Simpson's specially designed electoral instruments did their couching work well and Laycock soon began to see his way through the gathered pack of candidates to stand in sight of Bennett and Wood, the co-favourites for the chair. ${ }^{150}$

The seven week period between the announcement of Alison's resignation and Laycock's appointment gave professors in the Medical Faculty ample opportunity to lobby College Committee members and the Council at large in favour of promoting an

\footnotetext{
${ }^{149}$ See Laycock to William Finlay Watson, 7 August and 8 September 1855, Watson Collection, NLS MS 583, 840-1.

${ }^{150}$ For Simpson's account of his conduct in relation to Laycock and Bennett see A, 80, n 48, n 50, and transcribed in Supplementary Text 3: Press Cuttings, pp. 188-95 below. See also John Duns, Memoir of Sir James Y. Simpson, Bart., Edinburgh, Edmonston and Douglas, 1873, pp. 358-61, and my comments in the Biographical List, p. 217 below.
} 


\section{Michael Barfoot}

existing professor. In many respects, the most eligible incumbent was Robert Christison, Professor of Materia Medica since 1832. It appears that Christison's supporters made it known that he would accept the chair only if offered it outright (A, 68-9). By this time, however, the rule requiring a majority of twenty councillors had been dropped and the only way an open competition could be avoided was by the unanimous decision of the whole Town Council. Whether such an offer was made and Christison declined, or he withdrew beforehand, knowing the councillors disagreed among themselves, is unclear. ${ }^{151}$ A decisive factor, noted by Laycock in the 'Account', was that Christison's candidature did not have the full support of the Medical Faculty. This is likely to have been crucial in any behind-closed-doors broking that went on. The difficulty on this occasion revolved around plans for what was known as the "reversion" chair, the one vacated by promoting an existing professor. Friends of Douglas Maclagan, a well-connected lecturer in the Extra-Academical School saw an opportunity of getting their man into Christison's professorship should the latter become primus inter pares. However, another alliance was in the making between Syme and Bennett involving William Sharpey as reversion candidate for the Institutes' professorship. This threatened the alternative proposal. ${ }^{152}$ Each group knew how to mobilise support among councillors for their particular scheme. These squabbles and the appearance of other candidates such as Wood, Gairdner and Halliday Douglas waiting in the wings, made unanimity in the Council improbable. For whatever complex reasons, by the time Laycock returned on 10 September, it was clear that Christison was not in the race; a significant development, as many felt he could have won it, had he risked the canvass.

The electoral process took the form of lobbying. Pledges from councillors were solicited in advance with the aim of securing the necessary votes for outright victory. If more than two candidates went to the final vote, each councillor had a first and a second pledge to dispose of. This applied to Laycock's election and it complicated matters considerably. Although the private interview between candidate and councillor was the most obvious and direct means of securing such votes, in practice, lobbying was always a much more subtle process. The friends and constituents of the councillors were canvassed and they were expected to reciprocate by lobbying their representatives. In terms of enfranchised ten pounds voters, Edinburgh was still enough of a cheek-by-jowl town to sustain the extensive personal and social contacts which the whole process implied and indeed relied upon.

Alongside the real suffrages of the thirty-three councillors, there was probably a much larger hidden electoral college. Laycock stated that the whole town became progressively more interested in the latter stages of the contest $(\mathrm{A}, 82,91)$. As the excitement galvanised

\footnotetext{
151 See Robert Christison, The life of Sir Robert Christison, Bart., His Sons (eds), 2 vols, Edinburgh, William Blackwood, 1885, vol. 2, pp. 83-6. A letter to Councillor Hill dated "September" was reproduced by the editors to support the view that their father withdrew because of insufficient time to prepare, despite knowing that a unanimous offer of the Chair would eventually have been made.

152 See William Sharpey to Allen Thomson, 15 August, 2 September and 15 October 1855, in L. S. Jacyna (ed.), A tale of three cities: the correspondence of William Sharpey and Allen Thomson, London, Wellcome Institute for the History of Medicine, 1989 (Med. Hist., Supplement No. 9), pp. 85-9. Sharpey had been an extraacademical teacher in Edinburgh and subsequently became Professor of Physiology at University College. He indicated his willingness to be the reversion candidate if matters were so resolved in Edinburgh, but declined to lobby for it personally.
} 


\section{Introduction}

more and more citizens, the public mood and the activities of the "committees" $(\mathrm{A}, 73)$ came to resemble that of a municipal, or even a general election (A, 97, $n$ 97). The electioneering work which had to be done was such that no one candidate, however well connected, could carry on an effective campaign by himself. He required committees of supporters to act on his behalf. Laycock maintained he never had one (A, 74), and that he never entrusted his entire strategy to his supporters, citing the Religio medicorum episode to show his own independence from them $(\mathrm{A}, 83)$. Despite this, he was always willing for Simpson and his acolytes and other acquaintances such as Robert Chambers, D. R. Hay, John Lizars, Robert Cox, and William Macfarlane to work upon the virtual electoral college in his favour $(\mathrm{A}, 83) .{ }^{153}$ The fact that, as the day drew closer, the election result became more and more predictable to Laycock's and Bennett's supporters-and would have been so to Wood's had they read the unfolding events accurately-is an indication of how effective such committees could be. This was so to the extent that when Laycock went for a doze in Mr Watson's bookshop on Princes Street on the morning of the election, he already knew he would awaken Professor of the Practice of Physic (A, 97).

After Laycock had returned to Edinburgh to resume his campaign, he still knew perilously little of "the spirit of the people", their habits, and "the thousand minutiae which go to make up success" $(A, 58)$. Yet the municipal men he would have to convince were known to him as a type. He had similar origins to many of them. His dealings over the years with their counterparts in York gave him considerable insight into their social and cultural sensibilities (A, 72). Although by now a member of the Church of England rather than a Methodist, he still understood the dissenting evangelism which inspired many of them to perform their aedilitian duty. All this, and the fact that he had already contested for medical appointments in York, served him well.

His former correspondent, George Combe, from whom he could probably have expected useful local support, had unfortunately departed for Switzerland on health grounds (A, 97, n 101). However, others were standing by ready to assist. Some of his closest supporters Simpson, Chambers and Hay either came from similar backgrounds, or from once wealthy families who had fallen upon hard times. ${ }^{154}$ Simpson and Chambers understood the behaviour of the municipal mind in such situations particularly well. They professed publicly that the Town Council "always str[o]ve to put the right man in the right

\footnotetext{
153 Some of the election work done on Laycock's behalf can still be documented. See Journal of Robert Chambers, 12 September 1853-9 March 1857, W. and R. Chambers Papers, NLS Dep. 341, pp. 32, 63-7, where Chambers noted speaking to Bailie Kay and Councillor Cassels in Laycock's favour. See also Laycock to D. R. Hay, 9 and 26 September 1855, Volume of Letters Connected with the Aesthetic Club, in EUL MS Dc 2 58. Prior to the election, Laycock had corresponded with Hay about using one of the drawings from his book in a forthcoming article. See 'Further researches into the functions of the brain', Br. for. med. chir. Rev., 1855, 16: 155-87, on p. 181. For the original, see D. R. Hay, Natural principles of beauty as developed in the human figure, Edinburgh, W. Blackwood, 1852, p. 23.

${ }^{154}$ Duns, op. cit. note 150 above, pp. 94-111, portrays Simpson as a social outsider both before and after he obtained the Chair of Midwifery as he struggled repeatedly against the privilege and prejudice of the University Faculty of Medicine. In his Autobiography, NLS MF MS, p. 416, Chambers described his father's financial difficulties and extolled the virtues of busyness and self-help. Laycock's own experiences resulted in similar values. This is particularly evident in his first introductory lecture in Edinburgh at the beginning of the 1855-6 session, as reported in the Scotsman, 7 November 1855 . He told the students that "on commencing his career, he had as little prospect of obtaining this present chair as any of them". Shared phrenological interests apart, George Combe's social position at "the head of the yeomanry [rather] than the tail of the gentry", as Laycock once described himself $(\mathrm{J}, 158)$, would also have placed him firmly in the inner cabinet of Laycock supporters.
} 


\section{Michael Barfoot}

place" (A, 53, n 2), and knew privately that influence always counted. When exercising that highly political reflex function, these men never offended the sensibilities of the electors by employing methods more familiar to the horse traders who congregated in the Grassmarket (A, 82, n 55). For lobbying to be effective it had, almost unconsciously, to determine councillors' choice without appearing to take away their freedom to decide for themselves. It is easy to underestimate the belief shared by most councillors that "their sole duty was to elect the fittest man irrespective of all private considerations" (A, 74). Perhaps the most remarkable aspect of the whole election was that although the overwhelming majority of first and second votes were known in advance, yet each councillor pledged in the sincere belief that he was acting ultroneously. The resolution of this apparent contradiction implied a great deal of prior canvassing of opinion throughout the extended electoral lobby which Edinburgh gradually became. As the election drew closer, more and more people experienced a contagion of opinion about who was going to win.

\section{"Religious, political, academical and personal considerations" ( $\mathrm{A}, 83)$}

Thanks to Laycock's obsessive documentation, more is known about this episode than about any other Edinburgh professorship which changed hands between 1833 and 1858 . Yet the precise factors and circumstances which determined the Practice of Physic Chair in Laycock's favour still remain remarkably difficult to identify and interpret. The election was quite unlike the relatively simple Whig-Tory struggles in the latter days of the unreformed Town Council. ${ }^{155}$ From the available evidence, it appears that the government of the day was not involved or consulted in the manner it necessarily had to be in all crown appointments. ${ }^{156}$ Nor is there any evidence of national politics playing a direct role in determining the outcome. ${ }^{157}$

Since the Reform Act, Edinburgh's MPs were overwhelmingly Whig and the Council was predominantly of the same persuasion, although the electoral ward boundaries ensured a significant minority of Conservatives were always elected as well. ${ }^{158}$ Municipal Whiggery, however, had become something of a base alloy rather than the precious metal it once was in the early days of the Edinburgh Review. Now it consisted of the direct descendants of those sterling old Whigs, and liberal or radical Whigs, a newly pressed

\footnotetext{
155 See Christison, op. cit., note 151 above, vol. 1, pp. 77-8, 420-1, for remarks concerning the political influence brought to bear upon the contests during the early $1820 \mathrm{~s}$.

156 There is nothing in the Lord Advocate's records which indicates the government directly influenced decisions about Edinburgh professorships wholly in the gift of the Town Council. If anything, it was the Town Council who made their views known to government when regius chairs became vacant as, for example, when George Allman was elected to the Chair of Natural History immediately prior to the Practice of Physic contest. See Susan Sheets-Pyenson, 'Horse race: John William Dawson, Charles Lyell, and the competition over the Edinburgh Natural History Chair in 1854-1855', Ann. Sci., 1992, 49: 461-77, on p. 467.

157 The looser relationship between parliamentary and municipal representation after 1833 made it much more difficult to bring national political influence to bear upon professorial elections controlled by the Town Council. This is well illustrated by J. Y. Simpson's attempt to use his brother's influence as Bathgate electoral agent for the Hope interest in Linlithgo Burgh to bear upon the contest for the Midwifery Chair during late 1839 and early 1840. See W. Carmichael to Walter Grindlay, 18 November 1839, and John Hope to Walter Grindlay, 26 November 1839, Simpson Papers, RCSE MS 908, 907.

158 Williams, op. cit., note 115 above, p. 54. A rump of Conservative councillors were regularly returned in districts four and five of the New Town.
} 


\section{Introduction}

specie who were among the most vociferous opponents of old Whig tradition which they increasingly saw as conservative and elitist. Such groups tended to drop the "Whig" label altogether and refer to themselves as Liberals or Radicals. Also, Conservatism was no longer the Toryism which predominated in the Dundas days. Liberal or Peelite Conservatives were a different breed altogether, and the gap between them and those still clinging to the old Whig tradition narrowed considerably. ${ }^{159}$

This complex picture of party allegiances did not readily correspond to the politics of candidates presenting themselves for University medical chairs. As far as we know, most candidates, as professional men, tended to be of the old Whig or Conservative persuasion, having more in common with each other politically than with any of the other parties. This meant that Liberal and Radical councillors with their merchant and craftsman sympathies could rarely have chosen purely on party political grounds, even had they wanted to. Conversely, there was always enough leeway between the other two stances to enable old Whigs and Conservative professionals on the Council to vote for candidates of the opposite political persuasion with little difficulty. This is not to say that particular groupings did not have their preferred candidates, as in the case of Gairdner and the old Whigs, for example, but that party political preferences no longer dominated all other considerations.

If national party politics did not determine Town Council voting in professorial elections, most nineteenth-century critics and their successors agree that religious sentiment was a more decisive factor. Indeed, municipal politics was frequently driven by religious concerns. ${ }^{160}$ Countless disputes between Church of Scotland members, Free Church worshippers, United Presbyterians (1847), Episcopalians, Independents and other dissenters became the common fare of the day, and municipal wards could be won and lost on issues such as Sabbatarianism and the Annuity Tax. ${ }^{161}$ Allegiances were defined in relation to these and similar questions, with local political groupings identifying themselves in terms of voluntarism, non-intrusionism and the like. ${ }^{162}$ Moreover, there was interaction between religious and wider party political preferences which led to a bewildering variety of politico-religious positions. If the occasion demanded it, Radical political lions could lie with the Conservative lambs and one's position on Corinthians could be as important as on the Corn Laws. ${ }^{163}$

\footnotetext{
159 Ibid., pp. 62-5.

160 Williams, ibid., p. 93, argues that local Edinburgh politics and religion were inextricably intertwined, and that the Town Council's attitude to the University was always an effect and not a cause of sectarian political rivalries.

${ }^{161}$ Ibid., pp. 134-5. The annuity tax was a six per cent local tax levied to pay the stipends of Church of Scotland ministers in Edinburgh. For the wider religious background see Andrew L. Drummond and James Bulloch, The church in Victorian Scotland 1843-1874, Edinburgh, St Andrew Press, 1975; idem, The Scottish church 1688-1843: the age of the moderates, Edinburgh, St Andrew Press, 1973; Callum G. Brown, The social history of religion in Scotland since 1730, London, Methuen, 1987, pp. 28-56; Stewart J. Brown and Michael Fry (eds), Scotland in the age of the Disruption, Edinburgh University Press, 1993, pp. 1-112.

162 Voluntaries were anti-erastian dissenters generally opposed to any connection between Church and State. Non-intrusionists advocated similar views but within the Church of Scotland. Many of them joined the Free Church in the Disruption of 1843.

${ }^{163}$ For a description of the different politico-ecclesiastical parties in Edinburgh in the mid-1850s and the local newspapers which supported them, see Adam Black, Memoirs of Adam Black, Alexander Nicolson (ed.), Edinburgh, A. and C. Black, 1885, pp. 169-70.
} 


\section{Michael Barfoot}

The last actual controversy in which the Church of Scotland formally insisted upon an advisamentum over a proposed appointment by the Town Council was during the "Leslie Affair" in 1805. ${ }^{164}$ As the nineteenth century progressed, the statute in the Test Act of Queen Anne which demanded Scottish university professors' formal allegiance to the Established Church was quietly disregarded. ${ }^{165}$ Several University professors, such as James Syme and Charles Bell, were appointed although known to be Episcopalians. Prior to the Disruption of 1843, the sharp divergence of religious sensibility between members of the Council often resulted in canvasses driven by intense competition between moderates and evangelicals within and without the Established Church. Afterwards, the University and the Church of Scotland became in favour of the Tests being stringently enforced. Church membership clearly influenced elections to several professorships in the Faculty of Arts and matters came to a crisis when Free Churchmen were appointed to the professorships of Hebrew (1847) and Moral Philosophy (1850) and could not subscribe (A, 69). ${ }^{166}$ However in 1853, this aspect of the Tests was set aside by James Moncrieff's Act (16 \& 17 Vict., Ch. 89). For the first time, non-divinity professorships were formally open to conscientious Free Church members and dissenters. Rather than easing matters, this move probably intensified the religious element in some elections during the five years prior to $1858 .^{167}$

The influence of religion on appointments to medical chairs is likely to have been less pervasive than in arts subjects. Like the incumbent professors, candidates tended to be moderate Church of Scotland members or Episcopalians. Both denominations were probably religious minorities in mid-nineteenth-century dissenting Edinburgh. Simpson was among the minority of evangelical Free Church followers in the Medical Faculty after 1843. The 1855 election, coming so soon as it did after the Moncrieff Act, produced what was probably the first overt Free Church candidate for a medical chair. With the important exception of Simpson himself, it does seem that the bulk of Alexander Wood's supporters on and off the Council were of that persuasion (A, 97, n 93, n 97). Yet even here, the system of first and second voting meant that Free Church councillors' allegiances were by no means completely determined by religious considerations. For example, of the twelve

\footnotetext{
164 Ian D. L. Clark, 'The Leslie controversy, 1805', Rec. Ch. Hist. Soc., 1963, 16: 179-97; J. B. Morrell, 'The Leslie affair, careers, kirk and politics in Edinburgh in 1805', Scot. hist. Rev., 1975, 54: 63-82.

165 The Scottish Test Act (1706) was embodied into the Treaty of Union and required Scottish university professors and other teachers to subscribe to the Confession of Faith and to conform to the Church of Scotland in their form of worship. On the lapse of the Acts, see 'Memorial . . . to Peel . . . ', transcribed in Town Council Minutes, 27 February 1841, ECA SL7/1/241 (2 January-14 May 1841), pp. 216-24, on p. 222-3. See also Cockburn, op. cit., note 116 above, vol. 2, pp. 68-70.

166 See Grant, op. cit., note 91 above, vol. 2, pp. 75-8. For an insider view of professorial elections around this time, see David Dickson, Incidents of My Life, Edinburgh Central Library MS C5565, section entitled 'Town Council Life' (unpaginated). Rather like what Chambers said in public, Dickson wrote privately that the councillors of this period paid greater attention to the public good and principles of religion and were therefore "morally superior" in such respects than their admittedly more able and better educated successors. Dickson was himself a Free Church councillor and a Laycock supporter (A, 89). Unfortunately, the 1855 election is not explicitly discussed, either here or in his Journal, Edinburgh Central Library MS C5528-43.

${ }^{167}$ Perhaps the most celebrated instance of this was the defeat of J. F. Ferrier by the Free Churchman Alexander Campbell Fraser in the contest for the Logic and Metaphysics Chair in 1856. Having already lost the 1850 contest for the Moral Philosophy Chair in similar circumstances, Ferrier's criticisms of the management of University patronage at Edinburgh were not without pique. See his Letter to Editor, The Times, 17 August 1858, where he claimed that all the elections between 1843 and 1858 had been decided on sectarian grounds.
} 


\section{Introduction}

Free Church supporters who gave their first votes to Wood, Laycock noted that eight gave their second to him (A, 87).

The role of religion was not confined simply to support for their favoured man, it also extended to scrutinising the "orthodoxy" of the other candidates. Gairdner came under suspicion of being a Unitarian and had to explain why he left the Chapel on Castle Terrace only a short while before declaring himself a candidate, a move which suddenly deprived his former co-religionists of their organist (A, 70). ${ }^{168}$ Laycock cloaked his own heterodox views on the Resurrection and other aspects of revealed religion through formal membership of the Church of England. At the same time, he never quite burnt his Methodist boats either. Later in Edinburgh, he joined the Scottish Episcopalians. Notwithstanding his denominational surplice, Laycock was still open to criticism on wider religious grounds. He had been accused of "materialism" as a result of an article called "Further researches into the function of the brain' which appeared only weeks before he became a candidate $(\mathrm{A}, 62) .{ }^{169}$ Although Simpson thought the charge could easily be sent packing with one or two adroit testimonials from well-disposed dissenting and non-dissenting clergy, potentially it was a very serious obstacle to Laycock's success (A, 61, n 9). Since the early modern period, ideas about mind, matter, force and motion routinely used to explain human physiology were believed to have implications for God's role in creation and the immortality of the human soul. ${ }^{170}$ Laycock's use of comparative anatomy led him to underplay the differences between man and animals, while his account of cerebral physiology emphasised that thought processes were dependent upon brain function in a manner similar to phrenologists' views. ${ }^{171}$ Orthodox dualist opponents of these positions insisted upon a categorical separation between man and the rest of creation and rejected the notion that physicalist limitations should be imposed upon thought, which they interpreted as the activity of an immaterial spiritual principle. Their perceived antagonists were presented as monists who had a secret agenda which favoured the view that man was just an animal and thought was merely a property of matter. ${ }^{172}$

168 As Laycock noted (A, 62), 1855 also saw a controversy over whether Louis Agassiz, the Unitarian Swiss naturalist, should succeed Edward Forbes as Professor of Natural History. Earlier, in 1848, Martin Barry, the Quaker embryologist, had withdrawn from the Institutes of Medicine competition because he was unable to conform to the requirements of the "University Test", as it was then known. See Town Council Minutes ECA MS SL7/1/250 (4 May-6 November 1848), p. 149; Lancet, 1848, i: 645-6; ii: 107.

${ }^{169}$ Laycock's accuser, Henry McCormac was a fellow-candidate. Given the short interval between the publication of 'Further researches into the functions of the brain' and the contest, it is likely that the alleged remarks were made verbally. However, J.C. Bucknill, raised similar doubts when he reviewed the paper in $J$. ment. Sci., 1856, 2: 175-88.

${ }^{170}$ For the eighteenth century, see R. K. French, Robert Whytt, the soul, and medicine, London, Wellcome Institute for the History of Medicine, 1969, pp. 93-148. For the nineteenth, see Smith, op. cit., note 5 above, pp. 224-70. More generally see, John Hedley Brooke, Science and religion: some historical perspectives, Cambridge University Press, 1991.

171 Op. cit., note 1 above. Laycock argued that reflex functions formerly restricted to the spinal cord extended to the higher centres of the brain and that ideas could be produced without the intervention of consciousness. He first became interested in phrenology while a student at London University. For the affinity between his views and phrenology, see Laycock to Combe, 1 November 1856, Combe Papers, NLS MS 7355, f. 55. Later, he wrote the article 'Phrenology' in the eighth edition of the Encyclopaedia Britannica, 1859, vol. 17, pp. 556-76, in which he clarified his views, arguing that phrenology was "only a department of the great science of medicine, resting, as medicine itself rests, upon the great but imperfect science of life". See also Clarke and Jacyna, op. cit., note 5 above, pp. 220-44; Robert M. Young, Mind, brain and adaptation in the nineteenth century: cerebral localization and its biological context from Gall to Ferrier, Oxford, Clarendon Press, 1970, pp. 9-53.

${ }^{172}$ For an overview see, L. S. Jacyna, 'Immanence or transcendence: theories of life and organisation in Britain, 1790-1835', Isis, 1983, 74: 311-29. 


\section{Michael Barfoot}

The 'Journal' shows that as early as 1839 Laycock was aware his ideas might be interpreted in this way. Referring to his final contribution on hysteria in the Edinburgh Medical and Surgical Journal, he noted, "I shall be called a materialist" (J, 207). ${ }^{173} \mathrm{He}$ took great pains in both his writings and lectures to distance himself from such charges. He emphasised the role of mind as an active force in Nature and defended man's place in creation on natural theological grounds. ${ }^{174}$ At least some of the arguments he had used were ones which most of the Edinburgh councillors already understood, having imbibed them long ago along with their Sunday school milk. Laycock was adamant about republishing his essay on medical ethics because, in the Religio medicorum, he had written not only against materialism from a broadly Christian point of view, but also against infidelity and scepticism in medical practitioners. ${ }^{175}$ Laycock's medical Fichteanism may not have convinced some of his professional and academic critics any more than his wider metaphysics of intelligence, force and matter had. Nevertheless, his broadly Christian medical ethics probably offered common ground for approval among the denominationally diverse Edinburgh councillors.

The wider relations of the Edinburgh medical corporations and the medical community at large were local political factors which also had a direct effect on the election. There is general agreement that, throughout this period, the Extra-Academical School made an increasingly important contribution to Edinburgh's reputation as a centre of medical education. ${ }^{176}$ The Royal College of Surgeons in particular played a significant role. ${ }^{177}$ Its members had always enjoyed a considerable degree of independence over University medical men and Edinburgh physicians generally. ${ }^{178}$ In the eighteenth century, most of them were surgeon-apothecaries, a term synonymous locally with the nineteenth-century

\footnotetext{
${ }^{173}$ In his final 'Analytical essay' on hysteria, op. cit., note 68 above, and in the Treatise, Laycock stressed his debts to the metaphysics of G. W. Leibniz, Nehemiah Grew and Ralph Cudworth, the Cambridge Platonist. This necessitarian tradition stressed the role of mind in Nature, but in a way quite different to the voluntarist assumptions usually associated with Newton's early followers and their nineteenth-century successors. It underpinned Laycock's physiological thinking which shows considerable affinities with the "Romantic Biology" tradition as well as the British necessitarians. For discussion of the interaction between Laycock's physiology and philosophy, see the references cited under note 5 above.

${ }^{174}$ Op. cit., note 1 above, p. 311; 'Further researches ...', op. cit., note 153 above, pp. 186-7; op. cit., note 63 above, preface (unpaginated); See also Hutchinson, op. cit., note 148 above, p. 30. However, results were mixed; questions about Laycock's metaphysical and physiological "orthodoxy" continued to be raised. For example, see Anon., 'Review of "Mind and Brain"', Edinb. med. J., 1860-61, 6: 151-61, on pp. 154, 156, 158-9.

175 Op. cit., note 64 above, pp. $4,14$.

${ }^{176}$ Most research has tended to concentrate on the contribution of the University medical school, but see Guthrie, op. cit., note 113 above, pp. 12-21. Representatives of other universities such as Sir James Paget, a contemporary of Laycock in his London student days, knew only too well the value of the Edinburgh extraacademical teachers. See Tercentenary festival, op. cit., note 134 above, p. 68.

${ }^{177}$ Rosner, op. cit., note 106 above, pp. 86-103, 141-60. See also Alexander Wood, Rational medicine, a vindication: the address delivered at the opening of the new school of medicine, Surgeon's Hall ..., Edinburgh, Maclachlan and Stewart, 1849, pp. 50-3. On the earlier period, see Rosalie Mary Stott, 'The Incorporation of Surgeons and medical education and practice in Edinburgh 1696-1755', PhD thesis, University of Edinburgh, 1984.

${ }^{178}$ See idem, 'The battle for students: medical teaching in Edinburgh in the first half of the eighteenth century', in Edinburgh's Infirmary: the 250th and 100th anniversaries of the Royal Infirmary of Edinburgh and the 100th anniversary of the Simpson Memorial Maternity Pavilion, Edinburgh, Lammerburn Press, 1979, pp. 1-9. See also Michael Barfoot, 'Pedagogy, practice and politics: the Gregory-Bell dispute and the nature of early nineteenth-century Edinburgh medicine', in M. Nicolson (ed.), Scotland's health and medicine, London, Routledge, forthcoming.
} 


\section{Introduction}

neologism "general practitioner" which replaced it. In this role they held considerable sway over the lives of the ordinary Edinburgh citizen and his family. As members of the Incorporated Trades they also had an important and influential voice in the Deaconry of the pre-Reform Town Council. The survival on the reformed Town Council of a nonfranchised Deacon Convener representing the Incorporations allowed members of the Royal College of Surgeons to exert a direct influence upon the Medical Faculty until the College formally withdrew from the Incorporated Trades in 1851. Prominent RCSE members such as John Lizars and John Renton had served long periods as elected councillors (A, 72; 87). This ensured that the interests of the College of Surgeons were always well represented. ${ }^{179}$ The parallel expansion of extra-academical medical education also meant that the former dominance which University physicians had exercised over their Royal College in the eighteenth and early nineteenth centuries could no longer be sustained. Hence a "College party" of physicians gradually emerged which tended to favour the extra-academical candidates Wood and Gairdner rather than Bennett, a professorial fellow. ${ }^{180}$

After the election was finally over, many thought the split between Bennett's and Wood's supporters had let a weaker candidate in (A, 97, n 93, n 97). The assumption behind these judgements was that Bennett's academic qualifications were superior. He certainly believed so, while Laycock thought his own were the best. Laycock's vignettes of the councillors who had voted for him placed special emphasis on how his testimonials secured votes, regardless of all other influences (A, 89). But in terms of significant publications and weighty testimonials, it would have taken a brave person to be dogmatic about the respective merits of Laycock and Bennett. They were remarkably evenly matched at this stage in their careers (A, 107, n 124). Gairdner was their junior but he already showed great promise (A, 97, n 92). Only Wood and Halliday Douglas looked inferior on paper. Even so, a respectable case could still be made for Wood's eligibility. ${ }^{181}$ In fact, councillors-or anyone else for that matter-had no way of making ex cathedra judgements based solely on publications and testimonials. There was no Archimedean point from which to award the chair on solely rational grounds and independently of other factors. Laycock's and Bennett's qualifications got them into the race; they did not win it for them, and the same was true for some of the other candidates. Laycock's stress upon

\footnotetext{
179 The presence of non-University medical men on the Town Council was an earlier cause of complaint. See General report, op. cit., note 120 above, pp. 7, 364, 392; Black, op. cit., note 163 above, p. 96 . For a defence of this special representation, see Report by the Lord Provost's Committee, on remit by the Town Council of Edinburgh, relative to the statements contained in the Report of the Burgh commissioners concerning the patronage and management of the University of Edinburgh, Edinburgh, Thomas Allen, 1835, p. 7.

180 The 1855 House of Lords decision favouring the Town Council's right to make a proportion of extraacademical classes count towards the University medical degree gave further impetus to the process already gathering pace within the College of Physicians. During the 1840 s and early 1850 s, there had been various clashes of interest with the University concerning proposed medical reform bills. See W. S. Craig, History of the Royal College of Physicians of Edinburgh, Oxford, Blackwell, 1976, pp. 261-3; 269-70. Professorial fellows were often suspected of furthering the University's interest at the expense of the College which made them unpopular with Edinburgh's ordinary practitioners. Bennett in particular was censured for his conduct there. See Council Minute Book, (3 November 1851-7 February 1857), RCPE MS, pp. 156-7, 159.

181 Wood, for example, had just announced the use of subcutaneous injections of morphine for pain relief. See his On a new method of treating neuralgia by the direct application of opiates to the painful parts, Edinburgh, Maclachlan and Stewart, 1855.
} 


\section{Michael Barfoot}

how some supporters were able to vote for him on purely intellectual grounds because of the superiority of his testimonials and publications was a further way of absolving himself when suffrages had to be obtained by morally objectionable means.

Laycock's personal code of polite gentlemanliness predisposed him to conduct his private canvassing in the manner advocated by Simpson and Chambers. The inner calculation of personal interest had to be masked by an outer shell of honourable affability. To put councillors at ease in personal interviews, "Dr Laycock" undoubtedly used all the psychological skills he had developed over the years to elicit information from reluctant patients. ${ }^{182} \mathrm{He}$ took the metaphor of an "advocate" pleading his "case" before a "jury" as his guiding principle, presenting his own at length, and no doubt enjoying one of those rare opportunities in life of being able to talk freely about personal achievements with complete impunity $(\mathrm{A}, 72)$. The whole approach suited his strong sense of propriety, and he was relaxed with the patrons as only a stranger might truly be. Used to dealing with rude hospital governors, backbiting mayors and treacherous York councillors (A, 82-3, $n$ 59-60, n 62-4), he admired their Edinburgh counterparts by comparison, albeit in a superior, professional sort of a way. He called some of the councillors who voted for him "Nature's gentlemen" (A, 89), men like the retired butcher and former "fast liver" [sic] Ex-Bailie Gray (A, 89). He also applauded the majority for disregarding his nationality. Sir John Forbes had written "Would you were a Scotsman!" but Laycock claimed to have found very little significant opposition on these grounds alone. Ironically, when the "Hibernior ipsis Hibernis" card was dealt, it was actually an English councillor who objected to Laycock's nationality (A, 91).

When asked for an opinion of the other candidates Laycock praised them, despite entertaining the disparaging views he was later to record in the 'Account' (A, 70). He also encouraged councillors and others to believe he was more of a lobcock than a Laycock, a rank outsider out on a jaunt from the provinces to improve his reputation back home. Yet all the while he was quietly gathering in the crop of second votes which fed his own success and starved out Bennett and Wood. However one judges this public performance, for such it surely was, his conduct was compared favourably with his two chief rivals and the perceived contrast was helpful to him in some quarters. The personal behaviour of candidates during the election did have an effect on its outcome, along with political, religious and academic considerations, as Simpson later pointed out in relation to Bennett's conduct (A, 80, n 50). ${ }^{183}$ Personal animosity and jealousies could also lead prominent supporters, such as John Lizars, to fall into line behind one candidate rather than another (A, 71-2). No one factor was decisive but, in permutation, they guided the complex formation of opinion which would eventually crystallise in the distribution of first and second votes.

\footnotetext{
${ }^{182}$ See Medical observation, 1st ed., pp. 78-81, where Laycock advocated allowing patients to speak at length about their illnesses so they could be psychologically assessed. From the time of his early work on female hysteria, he prided himself on being able to spot dissembling patients. See also 'Account', A, 57, for an example of what Laycock called his "practised professional eye".

${ }^{18.3}$ See also Sharpey to Thomson, 2 September 1855, in Jacyna, op. cit., note 152 above, p. 87, where Bennett was described as "over urgent and not over discreet".
} 
"Nothing decisive is known until a few days previously to the election" $(\mathrm{A}, 82)$

Laycock's interpretations on points such as the compulsive moral force of his publications and testimonials can and should always be subject to a hermeneutics of suspicion. However, his detailed descriptions of events, and the accompanying documentary material he painstakingly collected relating to them, do allow the final stages of the election to be reconstructed with some confidence. After the second phase of faceto-face canvassing which lasted from 10 to 19 September, he returned once more to York. Hardly back, he was immediately requested to leave again for "the final struggle". The system of a first vote leading to the elimination of the third candidate, and a second to decide between the remaining two, now became crucial. ${ }^{184}$ Its overall effect was to dilute yet further the manner in which "religious, political, academical and personal considerations" could be brought to bear by any one group.

The tactic of praising other candidates and underselling himself in carefully selected quarters lulled Wood and Bennett into discounting Laycock's chances until virtually the last moment. It would not have mattered how many second votes he could muster if he was thrown out at the first ballot, and Bennett and Wood both had good reason to believe he would be. A week before the election (26-27 September) Laycock only had seven promises of first votes, and one of those (J. Clark's) was subsequently withdrawn (A, 87, n 67). However, this was more than Gairdner's four and the single one for Halliday Douglas pledged by his cousin, Bailie Brown Douglas, a prominent member of the College Committee. ${ }^{185}$ When the two junior candidates subsequently withdrew, Laycock's shrewd cultivation of friendly relations brought their personal recommendations and more first and second votes from their erstwhile supporters (A, 87). By 30 September, his tally of first votes had gone up to ten, with Bailie G. Clark coming in to replace Councillor J. Clark's defection, Cassels and Dick moving from Gairdner, and Dickson's first vote finally coming down in favour of Laycock instead of Wood and in spite of the Council's Treasurer himself being a "warm" Free Church supporter.

Ten first vote pledges, however, were still one fewer than Bennett, while Wood had twelve. Suddenly it was realised that Bennett would be defeated by Wood at the second vote if he beat Laycock at the first, as then seemed likely $(A, 91)$. The tally calculated on the night before the election as Laycock's supporters sat around a table in the Café Royal came as a shock to Simpson, given his "finesse" between Laycock and Bennett (A, 93, 96, n 83-4). Here Simpson's personal animosity to Wood and the general rivalry between the Medical Faculty, Established Church, Conservative supporters of Bennett, and the Free Church, Extra-Academical, College of Physicians, Whig-Liberal leanings of Wood's friends began to exert a late but decisive influence.

Laycock's supporters managed to prise away more second votes which had been intended either for Bennett, or were still undecided (Crichton, Murray, Sibbald and Tullis)

\footnotetext{
184 This system was only used when three candidates went to the final vote, which also happened in the close election for the Pathology Chair in 1842. See Town Council Minutes, 9 August 1842, ECA MS SL7/1/237 (3 May-11 October 1842), pp. 66-9. Then, and on similar occasions, an alternative system was proposed. This involved the elimination of candidates by successive rounds of voting until an absolute majority was reached in favour of the remaining candidate. However, it was always rejected as an impractical way of proceeding.

185 Morrison was the convener and the other members were Fraser, Grieve, Richardson, Crichton, Bell, Blackadder, Murray, Hill and Sibbald.
} 


\section{Michael Barfoot}

(A, 92-3). In such situations, it was customary for the candidate with no hope of winning at the final vote to withdraw and so allow a straight contest between the remaining two (A, 93). However, Bennett insisted his pledgers stay pledged and he refused to step down, apparently because he still believed he had a good chance in the second ballot (A, 80, n 49, 51). Encouraged by Simpson, two of Bennett's erstwhile supporters, one firm and one apparently less so, then broke away and went with Laycock, putting the matter beyond all doubt $(\mathrm{A}, 96)$. As predicted, Bennett was eliminated at the first vote and Laycock went on to win the second by a majority of two.

In view of these last minute moves, was the leader writer of the Edinburgh News correct after all? Had the methods of the Grassmarket galloped into the City Chambers: mere horse trading inspired by religious, political and personal animosities? Such factors were certainly more evident in the latter stages, but not blatantly so throughout. Councillors always had to be persuaded by arguments based on academic reputation, teaching ability, personal qualities and other points. This did not ensure that the "best" man won. However, the winner was ipso facto the "popular" candidate. This point was made again and again by those who defended the Council's patronage of University chairs both before and after Laycock's election. It was always presented as a system of popular suffrage. ${ }^{186}$ The final outcome was a reflection of public opinion, not in the sense of a poll among the virtual electoral college, but through representatively elected councillors being receptive to the significant individuals and groups who actually set public opinion throughout the wider Edinburgh lobby. Moreover, the canvassing of opinion was itself a semi-public process, at least when compared with any proposed board of patronage whose private deliberations would involve a group of men selected, not elected, for the purpose. The election of professors by councillors was a remarkable Scottish social institution which, after the national and municipal reform acts, had been strengthened rather than weakened by the first tentative steps towards local democracy and wider institutional accountability. ${ }^{187}$

Laycock's remarkably frank account of the final deliberations of the Council did nevertheless reveal flaws in its exercise of patronage. Councillors, candidates and their friends had participated in what started out as an eightsome reel. Notwithstanding the new professor's disclaimer never to have danced too intimately with anyone himself, a lot of bumping, leaning on partners, and even the odd kick all took place as the election gathered pace. Perhaps his description of its closing manoeuvres is as near as Laycock's conscience and his pride would let him come to criticising a procedure very similar to the one he had denounced so roundly some fourteen years earlier at York. ${ }^{188}$ Psychopathological speculation aside, however, Laycock could hardly turn around and flatly condemn a system which had given the medical Fichte such a memorable victory.

\footnotetext{
186 Report by the Lord Provost's Committee, op. cit., note 179 above, p. 7.

187 See 'Report of the College Committee of the Town Council of Edinburgh; being an answer to the memorial of the Senatus Academicus respecting the Management of the University', Town Council Minutes, 27 October 1835, in ECA MS SL7/1/220 (15 October 1835-16 February 1836), printed sheet 3, opposite p. 160: "the University was begun by the influence of the citizens and their magistrates, contemporaries, perhaps the friends of KNOX and BUCHANAN; that it has ever since been supported by funds provided mainly, from the community ... the attempt to deprive the citizens of Edinburgh and their representatives, of the management of their own University upon hypothetical possibilities of others managing it better, may well excite astonishment and indignation".

${ }^{188}$ Op. cit., note 81 above, p. 369 , where the quotation is also reproduced.
} 


\section{Introduction}

Although he did not enter into a general defence of Town Council patronage, Laycock's subsequent remarks about the clinical medicine controversy of 1856-57 and the 1868 election for a new University Principal, continued to bear upon the general issue of university government. By the time he came to summarise the former in the 'Account', he had already given his version of the dispute in the Correspondence and statements and its Sequel. Re-presenting features of it in his last chapter carried an important new meaning. In this context, the implication was that in their attempt to impose a new arrangement of clinical teaching at the Infirmary without considering Laycock's views, the Medical Faculty and the Senatus showed they were still very much in need of supervision by an external authority.

In 1857 that authority still resided with the Town Council whereas, eleven years later, the principalship contest was fought within the structure of the 1858 reforms. Here Laycock's implied criticisms cut in the other direction and showed that the workings of the new Court of Patronage set up to elect the Principal and non-regius professors had not resolved any of the difficulties formerly associated with the Town Council. The new body consisted of seven members, four councillors and three University Court representatives. The material Laycock collected about the competition between Simpson and Alexander Grant reveals that curators of patronage were equally subject to lobbying, the difference being that they were neither popularly elected, nor were their deliberations subject to public scrutiny (A, 112-14). These were the key objections made by supporters of municipal patronage against Hamiltonian boards specially appointed for the purpose. ${ }^{189}$ Laycock's refusal to come forward either to applaud the old or condemn the new shows he had learned the lessons of Sir William Hamilton well (A, 97, n 100). ${ }^{190}$ He probably viewed both arrangements on a par with his comments on religious sects in the 'Journal'- "imperfect agencies adapted to an imperfect state of society" (J, 238 and quoted above p. 16).

\section{"The stimulus of combat and hope was already lost in the certainty of victory" $(A, 96)$}

Although Laycock continued to add original sources to document the post-1855 controversies, this was done in a much more limited, almost cursory way. Despite vestiges of the documentary method, Laycock organised his final chapter around personal assessments of how Bennett, Christison, Syme and Simpson had conducted themselves towards him. One consequence of his allusive ad hominem approach is that it does not allow the kind of detailed re-examination of events using primary sources which is possible for his election. When he resumed the 'Account' after 1866, Laycock seems to have become less concerned with documenting the history of later episodes of his life in Edinburgh. Instead, his story turned inwards and took a further "moralizing" turn (J, 42).

\footnotetext{
189 See Report by the Lord Provost's Committee, op. cit., note 179 above, p. 25; Correspondence relating to the Principalship Contest between J. Y. S. and Sir Alexander Grant, Simpson Papers, RCSE MS 975-1050.

190 In a subsequent application for permission to teach medical psychology, Laycock presented himself as a follower of Hamilton's “principles of psychology". See Town Council Minutes, 22 September 1857, ECA MS SL7/1/272 (28 July-30 October 1857), pp. 273-6. Hamilton's doctrine of "latent consciousness" was similar to Laycock's ideas of reflex function of the brain and Carpenter's "unconscious cerebration". These men, along with J. D. Morell $(E T, 40)$ were all indebted to the same tradition of necessitarian metaphysics.
} 


\section{Michael Barfoot}

In composing his narrative Laycock never sought to heighten suspense by holding back the result of the election. Rather, in the very first sentence, he made it clear that "Dr Laycock", the omniscient third-person narrator, had won and was now the incumbent professor (A, 53). Also, because he stressed the manner of canvassing and how it enabled him to predict the outcome before any votes were actually cast, this ruled out a story built around an unexpected election result $(\mathrm{A}, 82)$. The approach he chose instead was a more subtle but ultimately no less dramatic one. First, he set the scene in terms of those high ideals which had led him to be a candidate. The chair, he wrote, would "give him the occasion to carry out an ambitious dream he had of re-modelling the science and practice of medicine in accordance with the progress of modern science" (A, 54). Even as late as 4 December 1857 he recorded in the 'Journal' that his aim was

to revolutionize mental science or metaphysics-to do that for it, what Bacon did for physics. In every branch of medicine I develop new views and new ideas. On every hand with few exceptions-I meet with opposition, distrust[,] lukewarmness. This is natural. And yet there is a feeling of justice in the public mind towards me which will in time find utterance. $(\mathrm{J}, 242)$

In view of such statements, any reader unfamiliar with Laycock's later career in Edinburgh might very reasonably expect the final chapter to describe how the medical Fichte did indeed "leave upon the profession a stamp of goodness and greatness that would not easily be effaced" $(A, 54)$. There is certainly very little to prepare a reader for Laycock's postscriptal remark that "for the future there was to be for him no brilliant success. Happy if he were not borne down and become a total failure" (A, 102). In fact, the 'Account' had been composed in its entirety with precisely this awareness at the forefront of Laycock's mind and this is where its real dramatic impact stems from.

The chair may have been the pinnacle of his career but his tenure was not without regrets. He had won the battle over clinical teaching, but was already loosing the war of attrition for public favour. Perhaps as a result of this episode, his health broke down in 1858 and he was unable to lecture for some time. When he commenced the 'Account' on 16 August 1860, Mind and brain had either just come out, or its publication was imminent. Either way, it appeared only to be submerged in the wake of Darwin's Origin of species (1859). ${ }^{191}$ Personal circumstances also affected the composition of his last chapter. On Christmas Eve of 1860 Edmund, his first son, died. He recommenced writing it while recuperating from the amputation of his left leg above the knee, which was performed by "dismal Jemmy" Spence in 1866. Laycock insisted on going through the operation without an anaesthetic. ${ }^{192}$ Conscious once again of his own mortality, he continued to add material

191 Charles Darwin, The origin of species, London, John Murray, 1859. The preface of Laycock's book is dated 16 April 1860. For Laycock's remarks on Darwin, see Mind and brain, 1st ed., vol. 1, pp. 361, 365; Evolution and Reversion, Laycock Collection, RCPE MS box 7, file 44. For Darwin on Laycock, see, Expression of the emotions in man and animals, London, John Murray, 1872, pp. 339-40.

192 Thin, op. cit., note 2 above, p. 90 . The condition necessitating the operation was reported as "destructive arthritis of the knee" at the time, and later as "tubercular disease of the knee-joint". Laycock made one brief allusion to it in the 'Account' when he referred to the fact that he did not attend Simpson's funeral because he was unable to walk at the time (A, 112). See also Laycock to Secretary of University Court, 27 September 1866 (copy), Edinburgh University Court Minute Book, in EUL MS Da 23.5, vol. 1, pp. 222-3. 


\section{Introduction}

after his wife's death in $1869(\mathrm{~A}, 112) .{ }^{193}$ In view of subsequent personal events in addition to the public controversies, perhaps it is not surprising that a subliminal wish to have lost the 1855 election should obtrude unconsciously into the narrative (A, 97). At the crucial point, when Laycock described the voting in the Council Chambers on 2 October, the name Councillor Grieve called out at the Council meeting which clinched the election was not "Wood", as Laycock wrote, but his own. ${ }^{194}$ Had the error been pointed out to him he would, no doubt, have interpreted it as further proof of the reflex function of his brain.

Amidst all this public strife, personal suffering and continued lack of professional recognition, Laycock wanted more than ever to explain the discrepancy between his bright ideals and the perceived failure of his tarnished professorship. He needed to meet the objection that the Town Council had, after all, chosen the wrong man. Chronicling and interpreting the events of the election was one way of doing this. Another was to describe the personal opposition he subsequently encountered from other medical professors. The latter was the real purpose of his concluding chapter with its gossipy, poison-pen portraits of Bennett, Christison, Syme and especially Simpson, his quondam ally (A, 102-14).

\section{"Envy, hatred malice, and all uncharitableness"' (A, 100)}

Throughout the published story of the Correspondence and statements and its Sequel, Laycock presented himself as a wholly innocent party who almost had been "borne down by the hardihood of assertion[s]" (S, 70) made by certain colleagues. In keeping with his ideal of gentlemanly conduct during public disputes, he could give his readers only hints of the personal animosity he believed Bennett, Christison and Syme had shown, and express his sadness that distinguished colleagues could behave so badly. However, immediately after a decision by the Town Council in Laycock's favour appeared to end the controversy, Simpson launched a new scheme to create an entirely separate chair of clinical medicine (A, 110, n 132). The emotional impact of this development was so powerful that it made Laycock "diarize under strangely altered circumstances" (J, 240-1). After a gap of nearly five years, he wrote:

I have been Professor of the Practice of Medicine in the University of Edinburgh since Nov. 1855 and have just closed a six weeks struggle with Profrs. Syme, Christison \& Bennett who have made an insidious[?] attempt to isolate me in Clinical Teaching. Dr S. has been my only supporter in the Faculty but now that I am victorious he apparently sets on foot another scheme more disastrous to me in its results if perfected than the other. So that if my surmise be true as to his ultimate objects he has only worked with me of late to keep me as his warming pan (J, 241). ${ }^{195}$

193 Laycock got the date of his wife's funeral wrong by a year (A, 112).

194 The Town Council Minutes, 2 October 1855, ECA MS SL7/1/266 (17 July-1 December 1855), pp. 207-10, the newspaper reports and his letter to his wife $(A, 97 \mathrm{n} 92,90)$ confirm this was an error. Laycock made a similar mistake earlier when he wrote of travelling between London and York meditating on the campaign (A, 85 ), when it should have been Edinburgh and York. The final psychologically revealing aspect of the manuscript occurs when he spoke of Bennett as "the most unscrupulous of men to deal with" $(A, 104)$, having first written "Laycock" and then crossed it out. This is one of the very few deletions in the entire manuscript.

195 See Laycock's letters to Simpson during the course of the 1857 dispute and other material in Simpson Papers, RCSE MS 924-5, 930-1, 923, 932. 


\section{Michael Barfoot}

The 1868 contest for the principalship involving Simpson and Sir Alexander Grant offered Laycock the opportunity of a final and uninhibited review of Simpson's conduct towards him throughout their long association. Apart from the clinical medicine episode, the list of accusations he made against the Professor of Midwifery was a long one. Laycock considered Simpson responsible for his son's constitutional weakness, believing that as a young child, he had been over bled on Simpson's advice (A, 100). He indicted Simpson for a breach of medical confidentiality when Simpson encouraged a rumour that he was dying of consumption in 1858 in order to inaugurate a new bout of election fever regarding his successor $(A, 102)$. He also sought to show how Simpson had worked to deny him consultations in and around Edinburgh, much to the detriment of his private practice (A, 100). Finally, Laycock pointed to a further scandal involving the Court of Patronage when the "old chairmaker's" influence stretched beyond the walls of Warriston Cemetery, where he had recently been buried after a public funeral, and ensured the succession of A. R. Simpson, his nephew, to the Midwifery Chair (A, 111). ${ }^{196}$

By privately recording scandalous rather than substantial details of how Simpson, Bennett, Syme and Christison impeded and belaboured him in a succession of controversies, Laycock was indulging what had become a life-long obsession to record how others behaved badly towards him. This is the connecting thread between the 'Journal' and the 'Account', despite their apparently dissimilar narrative forms. Laycock began the 'Account' on 16 August 1860, five years to the day since he embarked on the train journey to Edinburgh in quest of the chair. These significant and psychologically important dates constituted the proleptics of his inner life. He seems to have seen them as marking periods of personal change which, in turn, determined his future prospects. He also recorded them in much the same way as he had attempted to chart the effects of periodicity upon health and disease. Just as he resumed his 'Journal' at key moments, in later years, he also returned to the 'Account', probably with added satisfaction on the occasions he was able to add obituaries and photographs of three of the four of the "medical giants" with whom he had battled from the late 1850 s to the early 1870 s. ${ }^{197}$

In such moods, he did not care to dwell upon how like them he had become, or perhaps had always been. Any areas of common concern which did emerge from time to time, such as when he and Christison joined forces to oppose women medical students; or when they collaborated to study the therapeutic antagonism of drugs for the British Association, passed unmentioned. ${ }^{198}$ Probably he would have felt completely betrayed by any suggestion that "envy, hatred malice and all uncharitableness" might also be a characterisation of his own prose.

In the later sections of the 'Account', he never said much about his pioneering work as a teacher of medical psychology or about his role in the Medico-Psychological

\footnotetext{
196 See the collection of press cuttings on this subject in Scrapbook of W. G. Simpson, Simpson Papers, RCSE MS 1871 (unpaginated).

${ }_{197}$ Macdonald, op. cit., note 3 above.

198 See Jex-Blake, op. cit., note 113 above, pp. 84-5, and Note M on p. 62. See also 'Report on the antagonism between the action of active substances, by Thomas R. Fraser, M.D., Secretary to the Committee consisting of Sir R. Christison, Bart., Dr. Laycock, and Dr. Fraser' in Report of the forty-second meeting of the British Association for the Advancement of Science; held at Brighton in August 1872, London, John Murray, 1873, pp. $124-8$.
} 


\section{Introduction}

Association. ${ }^{199}$ The publication of Mind and brain also went unremarked, along with other articles which, for all the controversy, still continued to pour from his pen unabated. In terms of intellectual labour at least, he lived up to the "Robore labore spe" motto engraved onto the window of his consulting room at 13 Walker Street. ${ }^{200}$ Alone in the privacy of his study, he continued to keep faith with his sacred vision of medicine, irrespective of his more public allegiance to the Scottish Episcopal Church. No doubt, there was also the comfort of the Thirty-Seventh Psalm, just as there had been when his uncle disinherited him; and also when he went to church with Simpson on the Sunday before the election and found it was the text for Dr Guthrie's sermon $(\mathrm{A}, 92)$.

For evil doers fret thou not thyself unquietly,

Nor do thou envy bear those that work iniquity.

For, even like unto the grass, soon be cut down shall they;

And, like the green and tender herb, they wither shall away. ${ }^{201}$

Encased in the armour of a private and very personal religion of Nature, he was silently and scientifically confident he would awaken at the resurrection, a transformed mind in a new body, with the prospect of an eternity to study their relations. In describing Simpson's failure to obtain the principalship as a "fitting nemesis" (A, 114), Laycock was completely unaware that he also captured his own earthly condition.

After his death in 1876, the obituary in the British medical Journal noted that at autopsy Laycock's brain weighed forty-eight ounces and "the convolutions were exceedingly numerous" ${ }^{202}$ This was a fitting compliment to a man who approved of the message of phrenology, if not the medium. In his 'On the reflex function of the brain', thirty-two years earlier, he wrote that as the convolutions of the brain are

made up of an extensive surface of cineritious neurine, we may estimate the number of ideas, the substrata of which may be contained in a square inch, as not less certainly than 8000 ; and as there must be an immense number of square inches of surface in the grey matter extended through the cerebro-spinal axis of man, there is sufficient space for millions. ${ }^{203}$

Many of Laycock's ideas still remain unravelled today. There is a pressing need to say what they were, and to explain how they became inscribed into his brain as part of the process of how one man became a physician in mid-Victorian Britain.

\footnotetext{
199 Laycock devoted one day of his Practice of Physic class to medical psychology, commencing this during 1857-58 winter session. He began short summer courses in 1859. His introductory lecture to the latter was first published as 'A plea for the conjoined study of mental science and practice . . , ', J. ment. Sci., 1866, 12: 174-88. See also 'The objects and organisation of the Medico-Psychological Association: the anniversary address', ibid., 1869, 15: 327-43. On his role in the latter, see Trevor Turner, "Not worth powder and shot": the public profile of the Medico-Psychological Association, c. 1851-1914', in Berrios and Freeman, op. cit., note 4 above, pp. 3-16, on pp. 7, 12.

${ }^{200}$ For Laycock's use of this motto in his teaching, see Laycock Collection, in RCPE MS box 21, file 141.

201 Psalms, 37: 1.

202 Br. med. J., obituary, op. cit., note 2 above, p. 448.

203 Op. cit., note 1 above, p. 15.
} 


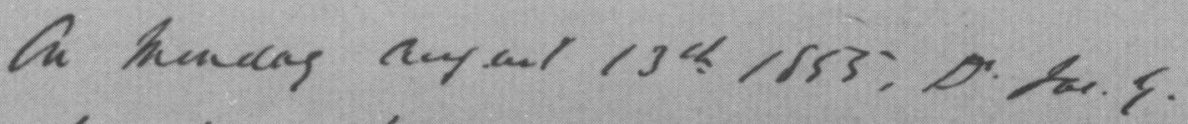

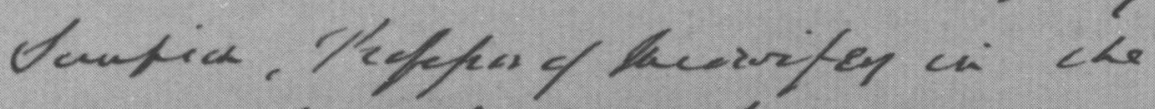

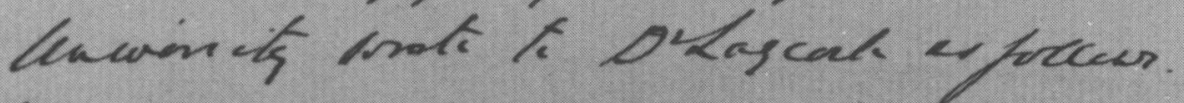

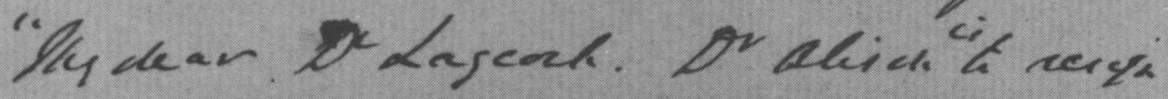
hiday ar trumas the clain of cke Rectice of Plequi, hi haneck Keng kad

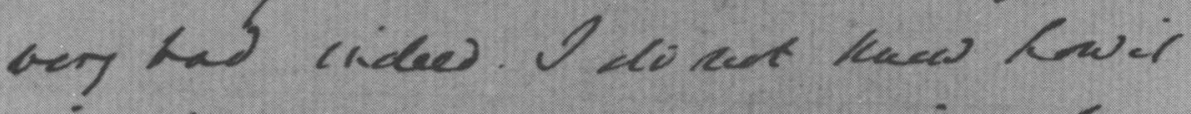
bile th deifued of a whe wiec be caurdeter for ir. Ded fentefe i coned

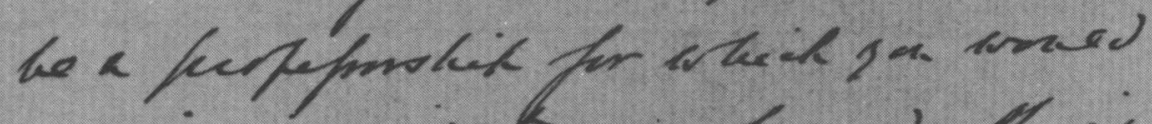

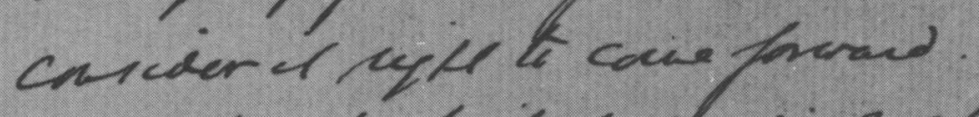

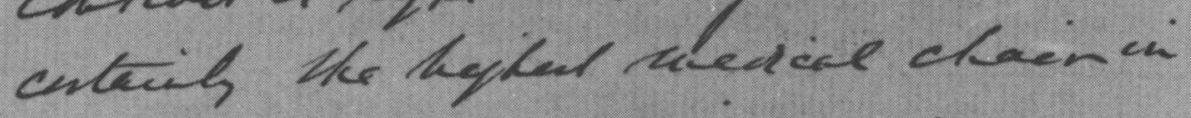

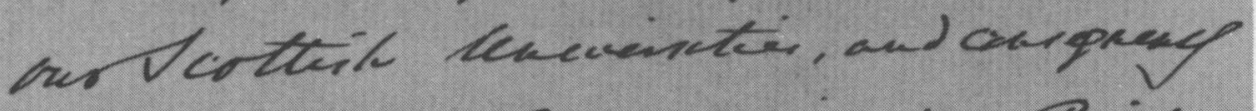
Uway rag ai feed Drebin. Reid

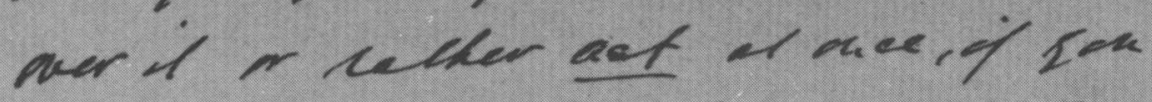

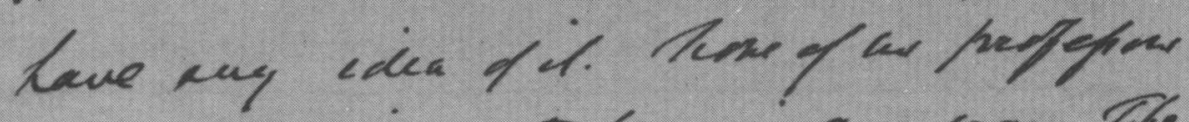
can or wole in toptue in avy aga. Dhe whole fohorye ci in the haces of the

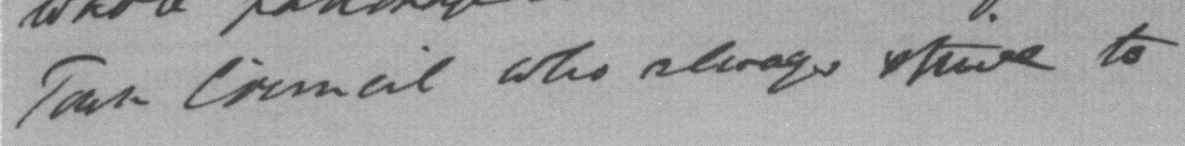
Figure 1: Second page of the 'Account'.

52

https://doi.org/10.1017/S0025727300071659 Published online by Cambridge University Press 